University of Nebraska - Lincoln

DigitalCommons@University of Nebraska - Lincoln

2000

\title{
Modeling regional salinization of the Ogallala aquifer, Southern High Plains, TX, USA
}

S. Mehta

University of Kentucky

A. E. Fryar

University of Kentucky

R. M. Brady

Panhandle Ground Water Conservation District No. 3

Roger H. Morin

Denver Federal Center, roger.morin49@gmail.com

Follow this and additional works at: https://digitalcommons.unl.edu/usgsstaffpub

Part of the Earth Sciences Commons

Mehta, S.; Fryar, A. E.; Brady, R. M.; and Morin, Roger H., "Modeling regional salinization of the Ogallala aquifer, Southern High Plains, TX, USA" (2000). USGS Staff -- Published Research. 356.

https://digitalcommons.unl.edu/usgsstaffpub/356

This Article is brought to you for free and open access by the US Geological Survey at DigitalCommons@University of Nebraska - Lincoln. It has been accepted for inclusion in USGS Staff -- Published Research by an authorized administrator of DigitalCommons@University of Nebraska - Lincoln. 


\title{
Modeling regional salinization of the Ogallala aquifer, Southern High Plains, TX, USA
}

\author{
S. Mehta ${ }^{a}, *$ A.E. Fryar ${ }^{\text {a }}$, R.M. Brady ${ }^{\text {b }}$, R.H. Morin ${ }^{\mathrm{c}}$ \\ ${ }^{a}$ Department of Geological Sciences, University of Kentucky, Lexington, Kentucky 40506, USA \\ ${ }^{\mathrm{b}}$ Panhandle Ground Water Conservation District No. 3, P.O. Box 637, White Deer, Texas 79097, USA \\ ${ }^{\mathrm{c}}$ US Geological Survey, Mail Stop 403, Denver Federal Center, Denver, Colorado 80225, USA
}

Received 22 November 1999; revised 15 August 2000; accepted 21 August 2000

\begin{abstract}
Two extensive plumes (combined area $>1000 \mathrm{~km}^{2}$ ) have been delineated within the Ogallala aquifer in the Southern High Plains, TX, USA. Salinity varies within the plumes spatially and increases with depth; $\mathrm{Cl}$ ranges from 50 to $>500 \mathrm{mg}^{-1}$. Variable-density flow modeling using SUTRA has identified three broad regions of upward cross-formational flow from the underlying evaporite units. The upward discharge within the modeled plume area is in the range of $10^{-4}-10^{-5} \mathrm{~m}^{3} \mathrm{day}^{-1}$, and the TDS concentrations are typically $>3000 \mathrm{mg}^{-1}$. Regions of increased salinity, identified within the Whitehorse Group (evaporite unit) underlying the Ogallala aquifer, are controlled by the structure and thickness variations relative to the recharge areas. Distinct flow paths, on the order of tens of $\mathrm{km}$ to $>100 \mathrm{~km}$ in length, and varying flow velocities indicate that the salinization of the Ogallala aquifer has been a slow, ongoing process and may represent circulation of waters recharged during Pleistocene or earlier times. On-going pumping has had negligible impact on the salinity distribution in the Ogallala aquifer, although simulations indicate that the velocity distribution in the underlying units may have been affected to depths of $150 \mathrm{~m}$ after 30 years of pumping. Because the distribution of saline ground water in this region of the Ogallala aquifer is heterogeneous, careful areal and vertical characterization is warranted prior to any well-field development. (C) 2000 Elsevier Science B.V. All rights reserved.
\end{abstract}

Keywords: Ogallala aquifer; Salinization; Southern High Plains; Modeling; Texas

\section{Introduction}

Salinization is a major concern in managing limited water resources in arid and semi-arid regions. Such a problem exists in the northern part of the Southern High Plains of Texas, where saline plumes of combined areal extent $>1000 \mathrm{~km}^{2}$ are present in the regionally important Ogallala aquifer. Two plumes lie

\footnotetext{
* Corresponding author. Duke Engineering and Services, 1180 Town Center Dr., Las Vegas, NV 89144, USA. Fax: +1-702-2950438 .

E-mail address: sunilmehta@msn.com (S. Mehta).
}

above the Panhandle oil and gas field in Carson, Gray, and Roberts Counties, overlapping the Palo Duro and Anadarko basins (Fig. 1). The southern plume is referred to as the Carson-Gray Counties plume, while the northern plume is referred to as the Roberts County plume. Chloride concentrations within the plumes range from 50 to $>500 \mathrm{mg} \mathrm{l}^{-1}$ and total dissolved solids (TDS) from 400 to $>2000 \mathrm{mg} \mathrm{l}^{-1}$. Salinization has affected water quality for both domestic and industrial use, as well as the placement of future municipal wells.

Saline ground water in the Carson-Gray Counties plume was first reported by local residents prior to 


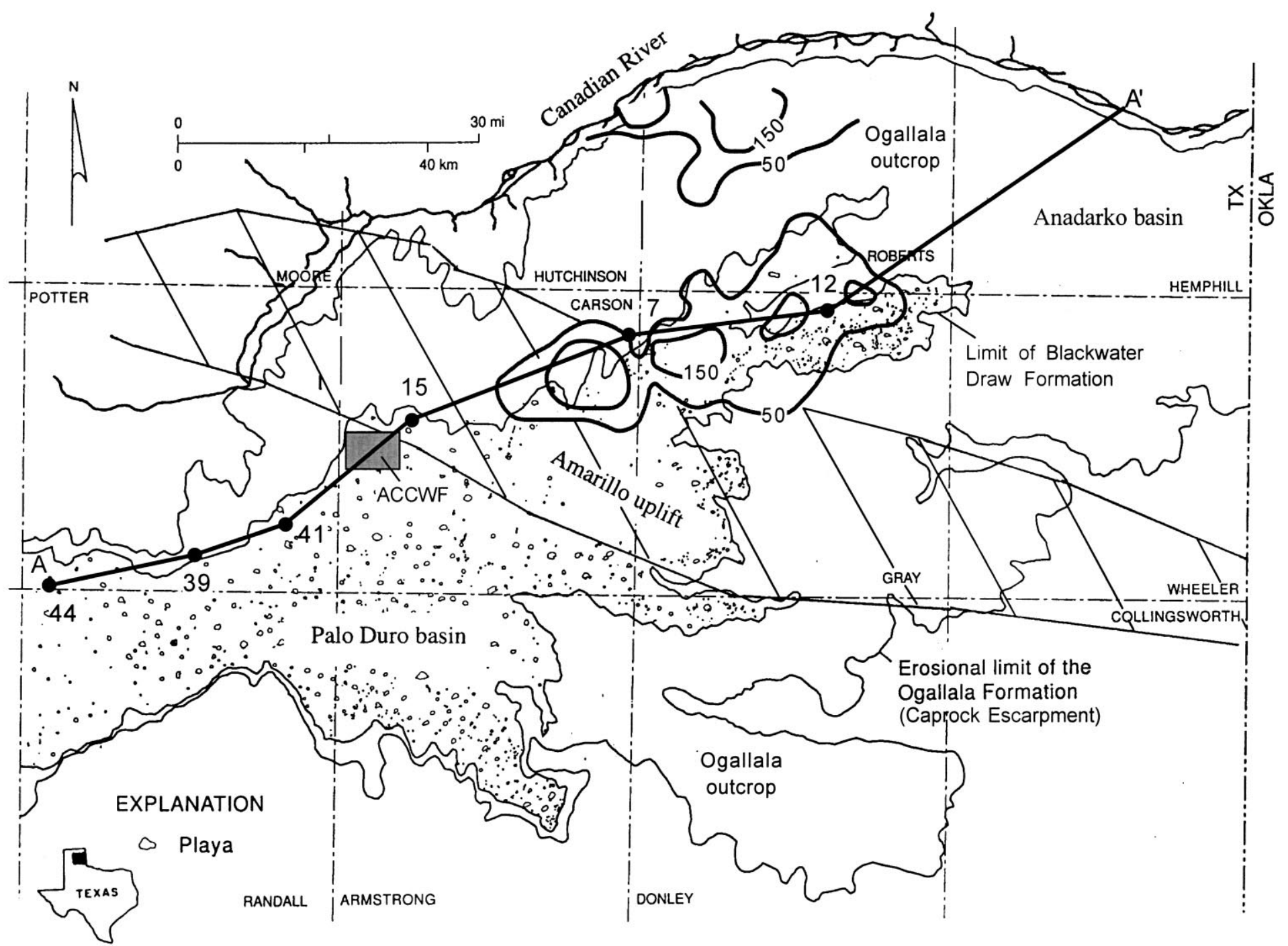

Fig. 1. Location of saline plumes in the study area. The chloride concentration contours are 50 and $150 \mathrm{mg} 1^{-1}$. The Amarillo uplift is hachured, and the Amarillo Carson County Well Field (ACCWF) is shown in a box. The stratigraphic cross-section along the bold line (A- $\left.\mathrm{A}^{\prime}\right)$ is shown in Fig. 2. The numbers represent well locations. Modified from Eifler and Barnes (1969), Mullican et al. (1997) and Mehta et al. (2000). 
1926 (Long, 1961) and was mapped by McAdoo et al. (1964). Mullican et al. (1997) developed a singlelayer ground-water flow model to evaluate recharge scenarios (diffuse vs. focused) in the area of the plumes, but did not address the salinity variations within the Ogallala aquifer. Using end-member mixing models with chemical and isotopic data, Mehta et al. (2000) showed that the increased salinity in the Carson-Gray Counties plume is largely unrelated to oil-field brines present in deep units. Instead, salinization results from the mixing of isotopically depleted, confined paleowaters with underlying saltdissolution zone waters, followed by upward discharge into the Ogallala aquifer.

This study extends the findings of Mehta et al. (2000) by attempting to: (a) delineate the nature of flow processes involved in increased salinity; (b) evaluate the structural and stratigraphic controls on solute transport; and (c) study the effects of on-going pumping on water quality. Other studies of salinization have focused on large salt lakes and disposal basins (Rogers and Dreiss, 1995; Narayan and Armstrong, 1995; Simmons and Narayan, 1998), saltwater intrusion in coastal aquifers (Segol and Pinder, 1976; Souza and Voss, 1987), brine movement on a basin scale (Senger, 1993; Lahm et al., 1998; Dutton et al., 1989), and evaporation (Stein and Schwartz, 1990; Sanford and Wood, 1991; Wood and Sanford, 1995). Our study differs in both the scale of the flow system and the mechanism of salinization.

\section{Hydrogeologic setting}

The Palo Duro and Anadarko basins are part of the intracratonic greater Permian basin, which formed as a result of late Paleozoic tectonic activity. The two smaller basins are separated by the fault-bounded, structurally high basement rocks of the Amarillo uplift (Fig. 1). The main topographic feature is the High Plains, which is separated from the Pecos Plains to the west by the Pecos River and from the Rolling Plains to the east by the eastern Caprock Escarpment. The Canadian River divides the Southern High Plains from the Central High Plains. In the northern part of the Southern High Plains, average annual precipitation is $50 \pm 10 \mathrm{~cm}$ and average annual pan evaporation is $250 \pm 25 \mathrm{~cm}$ (Gutentag et al., 1984; Luckey and Becker, 1999). The Neogene Ogallala Formation and Triassic Dockum Group form shallow aquifers, which are underlain by thick Permian evaporites (Table 1 and Fig. 2).

The unconfined Ogallala aquifer, which is the main water supply unit for the Southern High Plains, consists of fluvial sediments and fine-grained eolian silts and clays (Fig. 2). Estimated recharge rates vary from $0.145 \mathrm{~cm}$ year $^{-1}$ (Knowles et al., 1984; Senger and Fogg, 1987) to $0.9 \mathrm{~cm}_{\text {year }}{ }^{-1}$ (Mullican et al., 1997). Most of the recharge is focused through playas (ephemeral lakes that collect recharge) in the northern part of the Southern High Plains (Scanlon and Goldsmith, 1997). Ground water flows toward the northeast, following the regional topographic slope, and discharges naturally through springs and seeps along the Canadian River to the north and the Caprock Escarpment to the east (Mullican et al., 1997) (Fig. $1)$. The average flow velocity is $0.18 \mathrm{~m} \mathrm{day}^{-1}$ (Knowles et al., 1984) and average hydraulic conductivity is $8 \mathrm{~m} \mathrm{day}^{-1}$ (Senger and Fogg, 1987; Senger and Fogg, 1990; Mullican et al., 1997). The chemical composition of Ogallala ground water varies

Table 1

Generalized stratigraphic and hydrostratigraphic column for the study area (modified from Bassett and Bentley, 1983; Gustavson, 1986)

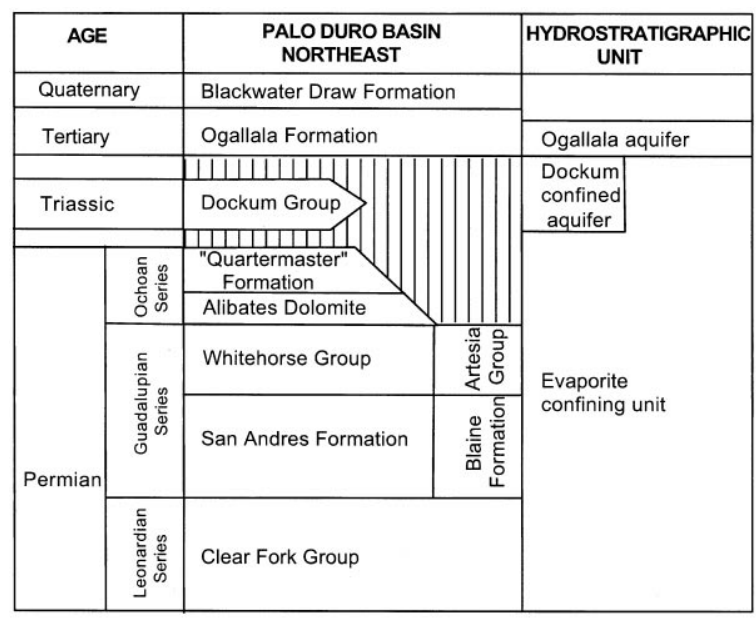

Hiatus 

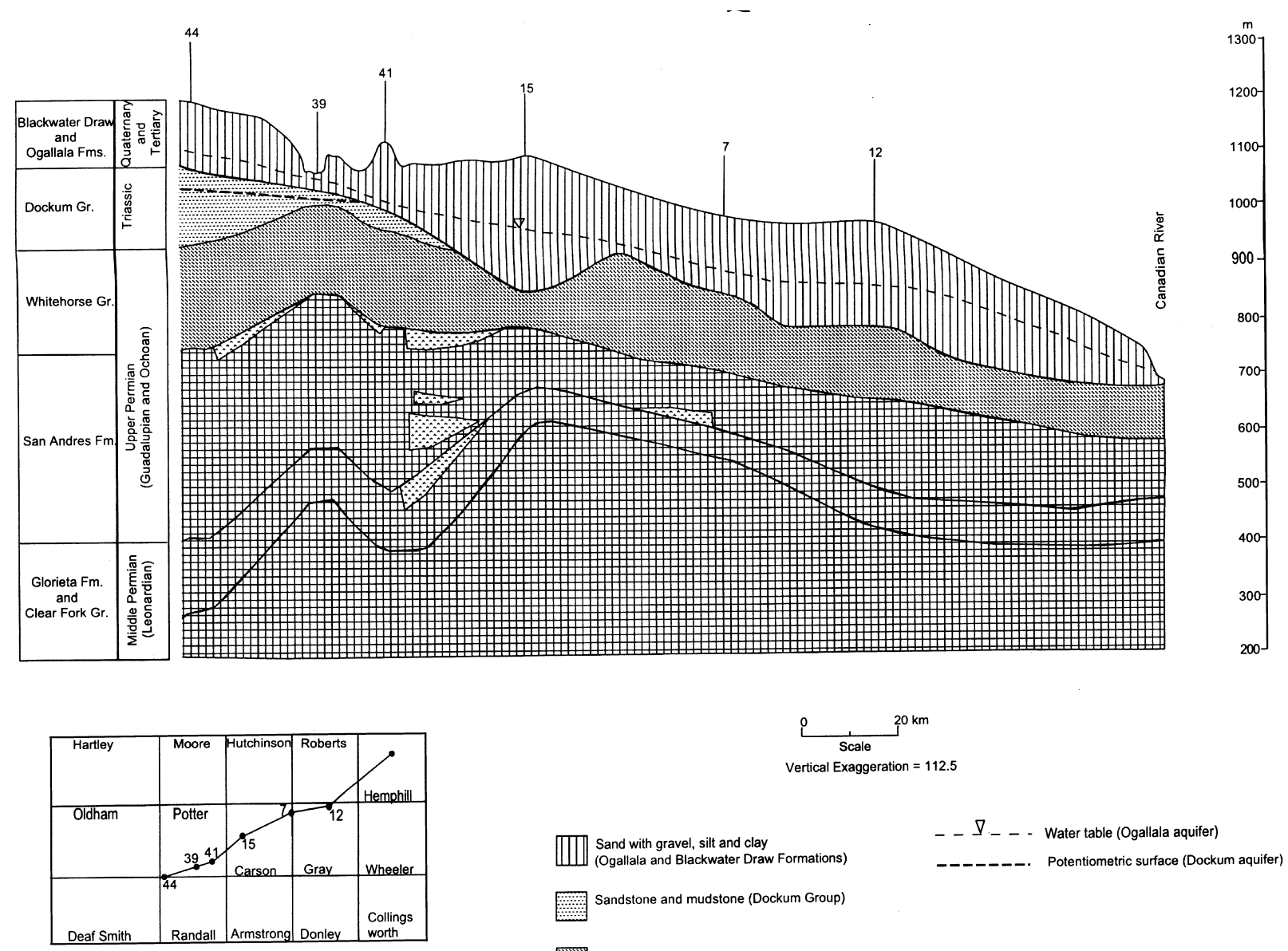

_ $-\nabla$. . . Water table (Ogallala aquifer)

Potentiometric surface (Dockum aquifer) 
from $\mathrm{Ca}-\mathrm{HCO}_{3}$ to mixed-cation- $\mathrm{HCO}_{3}$ water (Nativ and Smith, 1987). Pumping for irrigation started around 1911 and increased significantly after World War II. Water volumes currently being withdrawn from the aquifer are greater than the annual recharge and some areas have experienced water level declines of as much as $15 \mathrm{~m}$ between 1940 and 1980 (Dugan et al., 1994). Thus sustainability of ground-water resources is a major concern in this region.

The principal shallow confined aquifer is in the lower part of the Triassic Dockum Group, which is composed of sandstones and mudstones (Dutton and Simpkins, 1986; Dutton and Simpkins, 1989) (Fig. 2). The Dockum Group thins northeastward and pinches out approximately $40 \mathrm{~km}$ southwest of the western edges of the saline plumes. Present-day recharge to the Dockum aquifer is primarily through downward leakage from the Ogallala aquifer (Dutton, 1989; Dutton, 1995). The flow in the lower Dockum Group in the study area is toward the east-northeast and the water quality is marked by a mixed cation and mixed anion hydrochemical facies with TDS generally $<2000 \mathrm{mg} \mathrm{l}^{-1}$ (Dutton and Simpkins, 1986; Dutton and Simpkins, 1989).

The Middle and Upper Permian evaporiteconfining unit consists of halite, anhydrite, dolomite, limestone, and fine-grained siliciclastic red beds (Bassett and Bentley, 1983; Jorgensen et al., 1988) (Fig. 2). In the vicinity of the plumes, the Upper Permian Whitehorse Group, which is composed predominantly of siliciclastic red beds and minor evaporites (McGookey et al., 1988), is unconformably overlain by the Ogallala Formation. The Whitehorse Group can have significantly higher permeability than the underlying evaporite strata and locally acts as an aquifer where the Ogallala Formation and Dockum Group are thin or absent, such as at the margins of the Southern High Plains (Long, 1961). Several salt-dissolution zones have been identified within the upper part of the evaporite-confining unit (Gustavson et al., 1980; McGookey et al., 1988) (Fig. 2). These zones seem to have developed as a result of shallow, gravity-driven circulation of meteoric water (Dutton, 1989). Hydraulic conductivity ranges from $0.5 \mathrm{~m} \mathrm{day}^{-1}$ in salt-dissolution zones to less than $10^{-5} \mathrm{~m} \mathrm{day}^{-1}$ for the deeper parts of the confining unit (Dutton, 1989) and TDS varies from $5000 \mathrm{mg}^{-1}$ to
$>300,000 \mathrm{mg} \mathrm{l}^{-1}$, respectively (Nativ and Smith, 1987; Dutton, 1987; Bein and Dutton, 1993).

Dissolution is most extensive on the upturned flanks of the structurally high areas at the margins of the Palo Duro and Anadarko basins above the Amarillo uplift, where salt beds are nearest to land surface (Gustavson, 1986). As a result, the Whitehorse Group and equivalent formations have undergone more extensive dissolution compared to deeper units. The San Andres Formation has undergone limited dissolution, primarily toward the northeastern part of the study area. The Clear Fork Group forms the lower part of the evaporite-confining unit and does not undergo dissolution. Halite is the dominant lithology (Fig. 2).

In the Palo Duro basin, brine occurs in the haliteand anhydrite-cemented carbonate rocks of the San Andres Formation, whereas south of the Palo Duro basin, San Andres carbonates are significant oil reservoirs. The thickest San Andres carbonate bed in the Palo Duro basin, the informally named "unit 4 carbonate", yielded $0.35-2 \mathrm{~m}^{3}$ day $^{-1}$ of brine during drill-stem testing and long-term pumping (Dutton and Orr, 1986). Near-hydrostatic pressures exist in the San Andres Formation at depths of 790-927 m (6.769.03 MPa) (Dutton and Orr, 1986), but at greater depths, the San Andres Formation and Clear Fork Group show appreciable underpressuring, leading to potential downward cross-formational flow (Bair, 1987). Several reasons for underpressuring have been proposed and discussed by Bair (1987). An overall eastward flow is inferred for the San Andres Formation on the basis of a potentiometric surface map derived from equivalent freshwater heads (Bair, 1987).

\section{Plume characterization}

Mehta et al. (2000) mapped the Carson-Gray Counties plume, using chloride and sulfate data from existing records. Since then, more test wells have been drilled for the City of Amarillo and the Canadian River Municipal Water Authority (CRMWA) (Harden and Associates, 1999a, b; Lee Wilson and Associates, personal communication, 1999). These wells are located in Roberts County, where previous data were limited due to scarcity of monitoring wells. An updated map based on chloride 


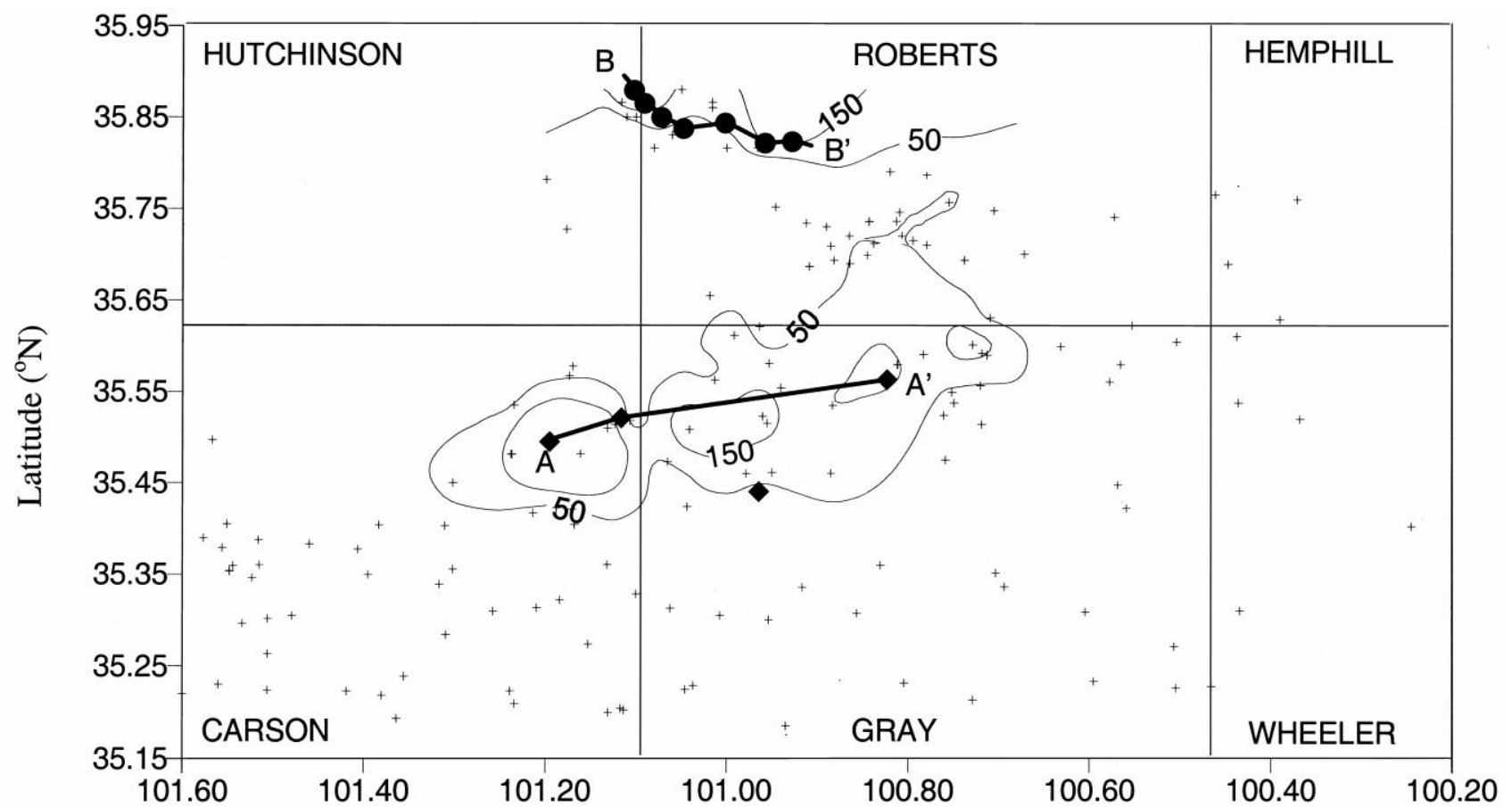

\section{Longitude $\left({ }^{\circ} \mathrm{W}\right)$}

Fig. 3. Plume outlines based on chloride concentrations. Contours are 50 and $150 \mathrm{mg} 1^{-1}$. Diamonds indicate wells logged in this study. Circles and plus symbols represent well data from Harden and Associates (1999b) and Texas Water Development Board database, respectively. Cross-sections A-A' and B-B' are shown in Fig. 5a and b, respectively. 


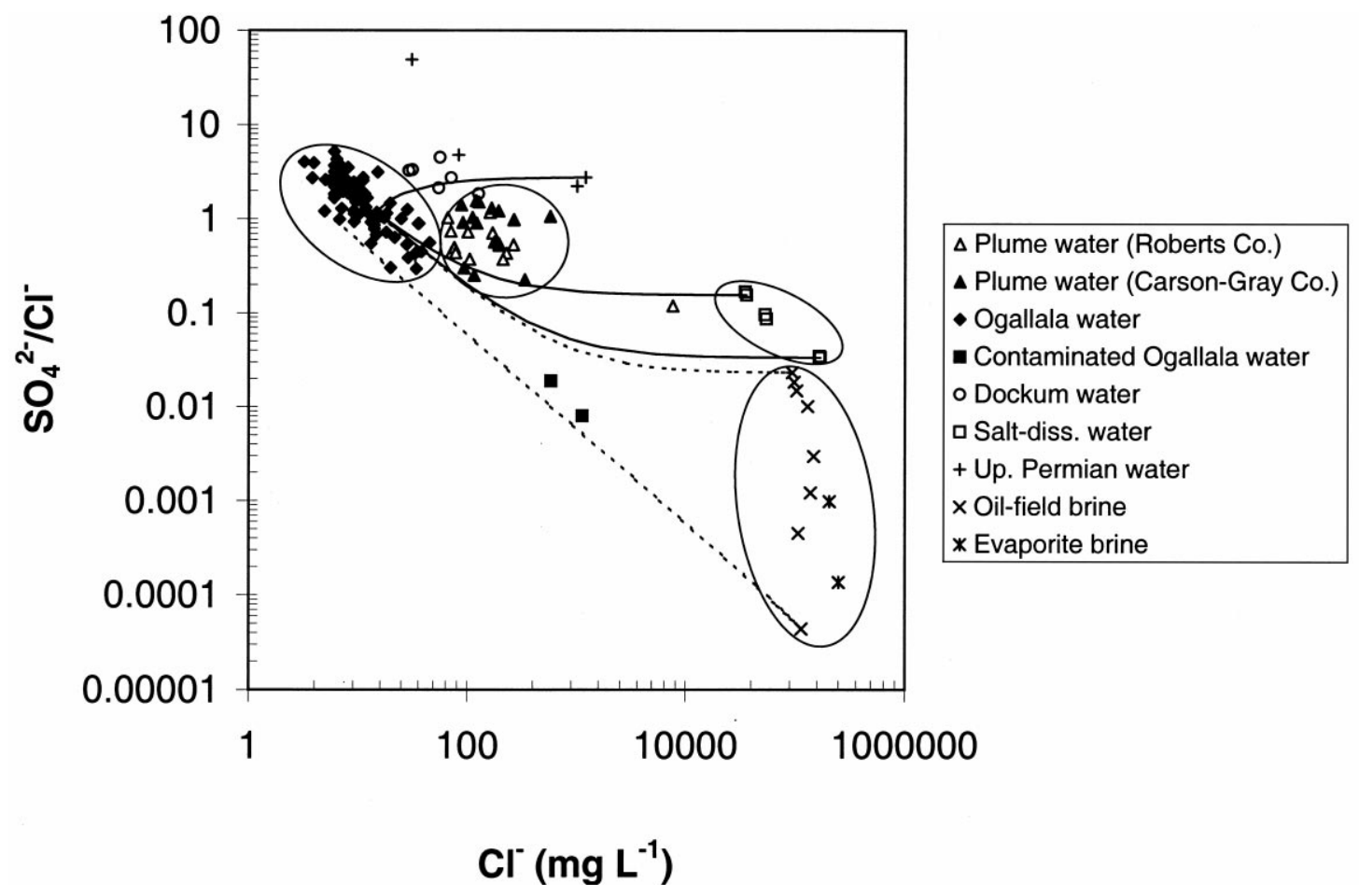

Fig. 4. $\mathrm{SO}_{4} / \mathrm{Cl}$ vs. $\mathrm{Cl}$ bivariate plot for end-member waters in the region (modified from Mehta et al., 2000).

concentrations shows two plumes of combined areal extent $>1000 \mathrm{~km}^{2}$ (Fig. 3). Sulfate concentrations have similar spatial distributions. The areal extent of the plumes and the distinct zones of high concentrations within the plumes indicate a regional source of salinity that is neither localized nor completely diffuse. Chloride and sulfate data of water samples from wells drilled in Roberts County (Fig. 4) fall in the compositional field of plume waters reported for Carson-Gray Counties plume by Mehta et al. (2000), indicating that both plumes have similar origins. The presence of the Canadian River to the north and probable dilution downgradient limits the known extent of the plumes. Salinization may be more extensive than mapped because the present plume geometry is controlled in part by the number and locations of monitoring wells.

We expected salinity within the plumes to increase with depth. In order to study the vertical distribution of salinity, four windmills were selected for fluid resistivity logging within the Carson-Gray Counties plume. No details of well construction were known for any of these windmills prior to this study. The selection criteria were based on the location with respect to the plume geometry and the distance from irrigation wells. All four windmills are located at least $1 \mathrm{~km}$ from known active irrigation wells. Three windmills are located close to the center of the CarsonGray Counties plume, and the fourth is located close to the edge of the plume (Fig. 3). Two of the four windmills had not been in use for more than two months before sampling, while the other two were continuously pumping. For all windmills, the production pipes, sucker rods, and check valves were pulled out at least $24 \mathrm{~h}$ prior to logging so that quasi-equilibrium conditions of solute distribution could return. Down-hole geophysical logging was carried out with a slim multifunction logging tool. Logging activities consisted of recording fluid temperature and fluid resistivity as well as natural gamma ray and caliper. The fluid resistivity logs were combined with corresponding temperature logs 


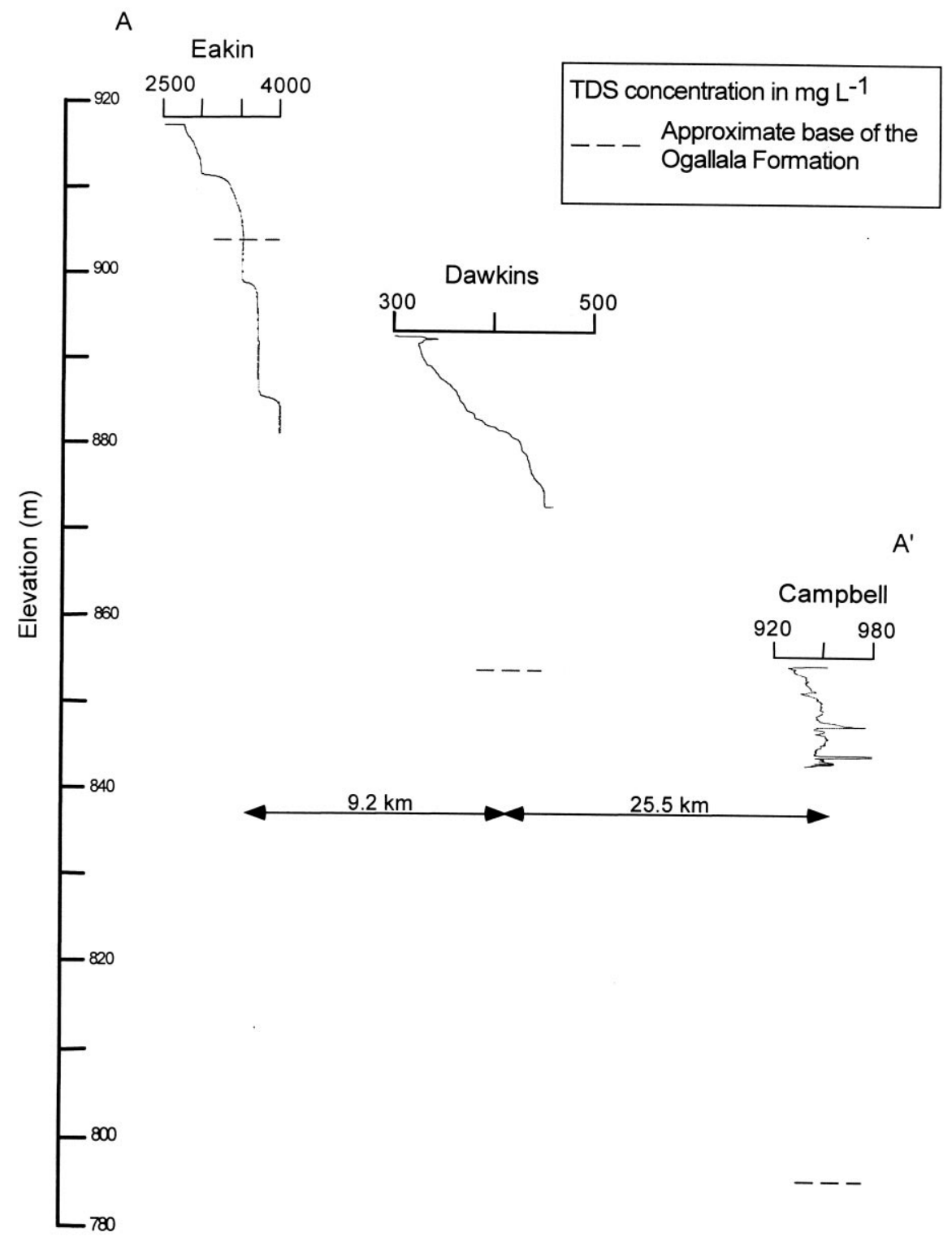

Fig. 5. (A) Fluid resistivity logs of selected windmills along cross-section A-A' shown in Fig. 3.

to compute the fluid resistivity (ohm-m) normalized to $25^{\circ} \mathrm{C}$ according to the formula (Paillet et al., 1990):

$R\left(T_{2}\right)=R\left(T_{1}\right)\left(T_{1}+21.5\right) /\left(T_{2}+21.5\right)$

and then converted to estimates of TDS $\left(\mathrm{mg} \mathrm{l}^{-1}\right)$ according to the relation (Fishman and Friedman,
1989):

$\mathrm{TDS}=\left(0.65 \times 10^{4}\right) / R\left(T_{2}\right)$

where $R\left(T_{1}\right)$ is the resistivity given at temperature $T_{1}\left({ }^{\circ} \mathrm{C}\right)$ that is extrapolated to the resistivity $R\left(T_{2}\right)$ at another temperature, $T_{2}\left(25^{\circ} \mathrm{C}\right.$ in this study). 


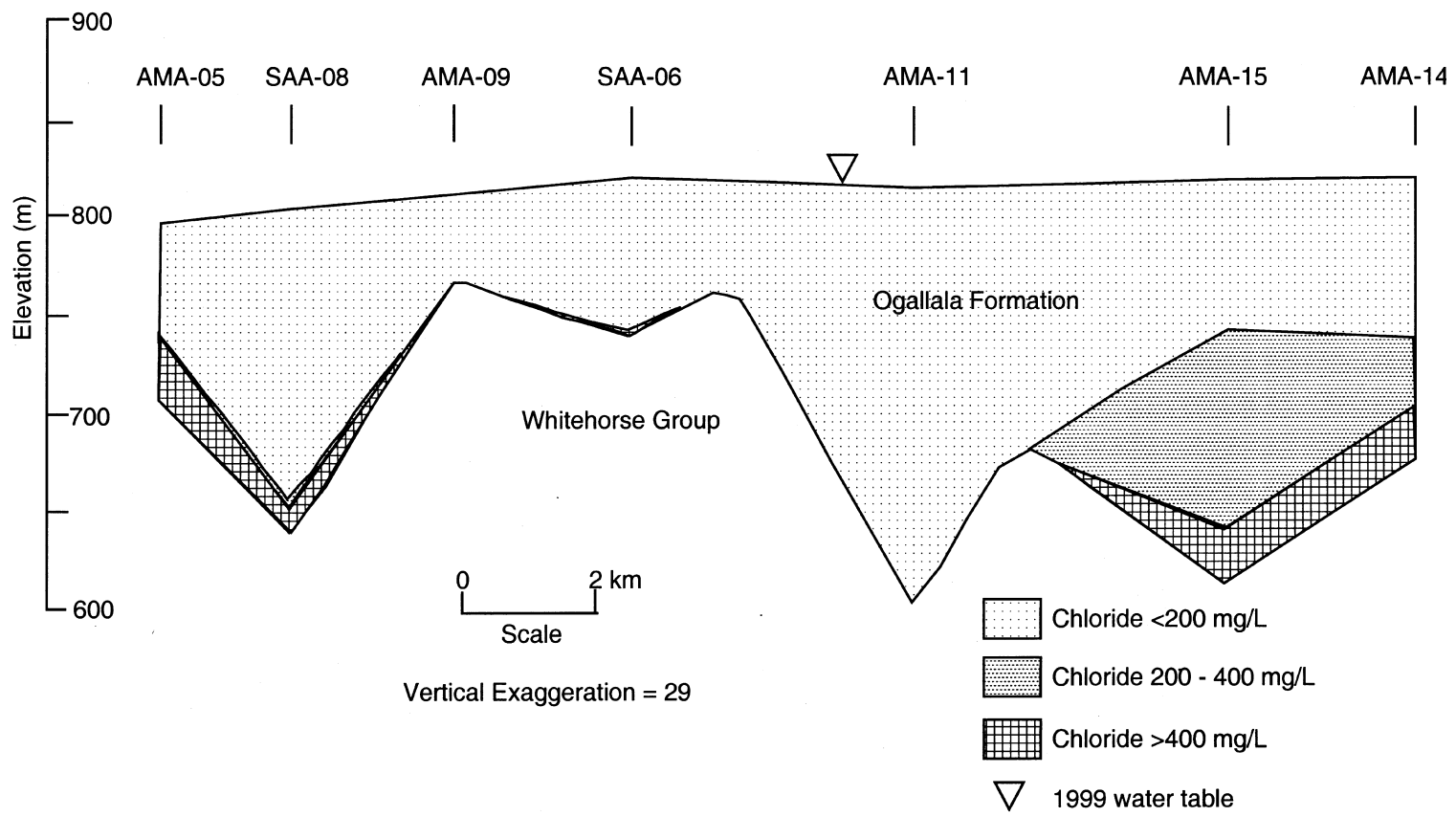

Fig. 5. (B) Chloride zonation for selected wells along cross-section B-B' shown in Fig. 3 (after Harden and Associates, 1999b).

The computed TDS profiles of the three windmills located close to the center line of the plume are shown in Fig. 5a. The Eakin well is screened across the bottom of the Ogallala aquifer and the underlying Upper Permian red beds. It displays strong salinity stratification with depth and TDS systematically increases to approximately $4000 \mathrm{mg} \mathrm{l}^{-1}$ near the bottom of the well. The Dawkins well is screened within the Ogallala aquifer and exhibits a gradual increase in TDS with depth that is an order of magnitude less than that observed for the Eakin well. The Campbell well displays intermediate TDS values that are more uniform with depth, probably because it is screened a considerable distance $(>40 \mathrm{~m})$ above the base of the Ogallala aquifer. The fourth windmill located south of the plume (Fig. 3) had a small saturated interval $(\sim 2 \mathrm{~m})$ and did not show any salinity variation (log not shown).

In a study by Harden and Associates (1999a,b), geophysical logging was performed for 33 wells and water quality was analyzed for five test wells in
Roberts County. All wells were screened within the Ogallala aquifer and many show increasing salinity with depth, as shown along cross-section $\mathrm{B}-\mathrm{B}^{\prime}$ (Fig. $5 \mathrm{~b}$ ). One of the test wells (located near the northwestern end of cross-section $\mathrm{B}-\mathrm{B}^{\prime}$ in Fig. 3) had TDS of $13,000 \mathrm{mg} \mathrm{l}^{-1}$ with chloride $>7500 \mathrm{mg} \mathrm{l}^{-1}$. The water sample from this well is plotted in Fig. 4 as an open triangle (plume water) located near the salt-dissolution zone waters and may represent mixing of salt-dissolution zone water with Ogallala water via cross-formational flow. The mixing zone cannot be mapped accurately because of the presence of the Canadian River to the north and the lack of wells.

In a separate study within Roberts County, Lee Wilson and Associates (personal communication, 1999) logged and sampled 11 test wells. Their results also show increasing salinity with depth (in one test well, $\mathrm{Cl}$ concentrations increased from 7 to $730 \mathrm{mg}^{-1}$ within a $100-\mathrm{m}$ interval). Both Fig. 5a and $5 \mathrm{~b}$ document that the saturated thickness of the 
Ogallala aquifer, by itself, does not control the salinity distribution. The saturated thickness of the Ogallala aquifer within the study area ranges from 15 to $>100 \mathrm{~m}$ and the hydraulic conductivity ranges from 1 to $28 \mathrm{~m} \mathrm{day}^{-1}$ (Mullican et al., 1997).

\section{Numerical modeling}

Mehta et al. (2000) hypothesized that salinization results from gravity-driven cross-formational circulation along flow paths tens of $\mathrm{km}$ long. We test this hypothesis and observe the effects of pumping on salinity in the Ogallala aquifer by using the numerical model SUTRA (Voss, 1984). SUTRA employs a twodimensional, finite-element method, with an implicit finite-difference approximation in time to simulate variable-density ground-water flow and solute transport. The method is stable and accurate when used with proper spatial and temporal discretization.

The fluid mass balance under saturated conditions can be expressed as (Voss, 1984):

$\partial(\varepsilon \rho) / \partial t=-\nabla \cdot(\varepsilon \rho V)+Q_{\mathrm{p}}$

where $\varepsilon(x, y, t)$ is a dimensionless porosity, $\rho(x, y, t)$ is the fluid density, $V(x, y, t)$ is the average fluid velocity, $Q_{\mathrm{p}}(x, y, t)$ is a fluid source or sink, $x$ and $y$ are coordinate variables, $t$ is time, and $\nabla$ is the divergence operator. This equation can be expressed in terms of two primary variables, $p$ (pressure) and $C$ (TDS concentration):

$$
\begin{aligned}
& \left(\rho S_{\mathrm{op}}\right) \partial p / \partial t+(\varepsilon \partial \rho / \partial C) \partial C / \partial t-\nabla \cdot[(\rho k / \mu) \cdot(\nabla \rho-\rho g)] \\
& \quad=Q_{\mathrm{p}}
\end{aligned}
$$

where $S_{\mathrm{op}}=(1-\varepsilon) \alpha+\varepsilon \beta$ is specific pressure storativity, $\alpha$ is porous matrix compressibility, $\beta$ is fluid compressibility, $C(x, y, t)$ is solute concentration as a mass fraction, $k(x, y)$ is permeability, $\mu(x, y, t)$ is fluid viscosity, $p(x, y, t)$ is fluid pressure, and $g$ is gravitational acceleration.

The solute mass balance for a single species at a point $(x, y)$ in an aquifer is given by (Voss, 1984):

$$
\begin{aligned}
& \varepsilon \rho(\partial C / \partial t)+\varepsilon \rho V \cdot \nabla C-\nabla \cdot\left[\varepsilon \rho\left(D_{\mathrm{m}} \mathbf{I}+\mathbf{D}\right) \cdot \nabla C\right] \\
& \quad=Q_{\mathrm{p}}\left(C^{*}-C\right)
\end{aligned}
$$

where $D_{\mathrm{m}}$ is molecular diffusivity of a solute in solution in a porous medium, $\mathbf{I}$ is the identity tensor, $\mathbf{D}(x, y, t)$ is the dispersion tensor, $C^{*}(x, y, t)$ is concentration of solute as a mass fraction in the source fluid, and $\rho(x, y, t)$ is fluid density given as a linear function of concentration:

$\rho=\rho_{\mathrm{o}}+(\partial \rho / \partial C)\left(C-C_{\mathrm{o}}\right)$

where $\rho_{\mathrm{o}}$ is fluid density when $C=C_{\mathrm{o}}, C_{\mathrm{o}}$ is a base solute concentration, and $\partial \rho / \partial C$ is a constant coefficient of density variability.

\subsection{Conceptualization, spatial discretization, and boundary conditions}

A cross-section of length $200 \mathrm{~km}$ and depth ranging from 900 to $500 \mathrm{~m}$ was chosen for modeling (Fig. 2). The cross-section approximately parallels the CarsonGray Counties plume orientation and the regional flow gradient for both the Ogallala and Dockum aquifers. We chose the length of the cross-section on the basis of well locations with good stratigraphic control and to include part of the Dockum Group. Upper and Middle Permian formation boundaries were delineated by lithologic and geophysical logs presented by McGookey et al. (1988). Thickness variations for the Ogallala and Dockum aquifers were incorporated from Mullican et al. (1997) and Dutton and Simpkins (1986), respectively. The top of the model was taken to be the 1959-1960 water table for the Ogallala aquifer. This surface approximates steady-state conditions because most of the irrigation pumping in the region started after 1960. Furthermore, pre-1960 water-level data are lacking because of scarcity of monitoring wells. Previous modeling studies in the region (Knowles et al., 1984; Mullican et al., 1997) also considered the 1959-1960 water table to represent steady-state conditions. The base of the model was arbitrarily chosen within the Middle Permian Clear Fork Group, which forms a good confining unit. The model cell thickness in third dimension is $1 \mathrm{~m}$.

Modeling was performed using the US Geological Survey's graphical-user interface for SUTRA (SUTRA GUI) as a plug-in extension (PIE) to Argus $\mathrm{ONE}^{\mathrm{TM}}$ (Argus Open Numerical Environments, commercial software developed by Argus Interware). We focused on accurately discretizing the geologic 
units in order to have a distinct top and bottom with finite elements aligned along the boundaries. A Fishnet Mesh (provided in SUTRA PIE) was used for this purpose (Voss et al., 1997). It consists of superblocks (large contiguous quadrilaterals), each subdivided into a specified number of quadrilateral finite elements such that the edges of the quadrilateral are connected to each internal node in $x$ - and $y$ directions. The mesh density can be varied within the model domain at user-specified locations.

The model cross-section was discretized into 180 elements in the horizontal direction and 32 elements in the vertical direction, resulting in a mesh containing 5760 quadrilateral elements and 5973 nodes. The horizontal mesh spacing varied from 700 to $1400 \mathrm{~m}$, with finer discretization in the vicinity of the plume and near the pinchout of the Dockum Group. The vertical spacing was determined by trial and error and ranged from $3 \mathrm{~m}$ for the Ogallala aquifer to $60 \mathrm{~m}$ for the Clear Fork Group. A grid convergence study was performed to insure proper grid discretization: a much finer grid (with grid spacing half of that used in the model) did not produce any appreciable difference in velocity and concentration distributions, despite being more computationally expensive.

The boundary conditions for simulation of flow and solute transport for the cross-section are shown in Fig. 6. A no-flow boundary is specified along the bottom of the mesh. The lateral boundaries from the top to the base of the San Andres Formation are specified pressure boundaries using fresh-water hydrostatic pressure $(p)$ varying linearly with depth such that $p=\rho_{\mathrm{w}} g d$, where $\rho_{\mathrm{w}}$ is the density of fresh water, $g$ the gravitational acceleration, and $d$ the depth below the water table. No-flow lateral boundaries are specified across the Clear Fork Group. A uniform recharge flux of $6 \mathrm{~mm} \mathrm{year}^{-1}$ is applied at the top boundary. This value was selected on the basis of modeling results presented by Knowles et al. (1984), Mullican et al. (1997) and Luckey and Becker (1999). Mullican et al. (1997) also found that using either areallydistributed recharge or playa-focused recharge gave similar results in predevelopment simulations for the Ogallala aquifer.

The solute concentrations at the lateral boundaries also vary. On the southwest (left) specified-pressure boundary, the concentrations given are $0.0002 \mathrm{~kg}$ $\mathrm{TDS} \mathrm{kg}^{-1}$ fluid $\left(200 \mathrm{mg} \mathrm{l}^{-1}\right)$ for the Ogallala aquifer,
$0.001 \mathrm{~kg} \mathrm{TDS} \mathrm{kg}^{-1}$ fluid $\left(1000 \mathrm{mg} \mathrm{l}^{-1}\right)$ for the Dockum Group, $\quad 0.005 \mathrm{~kg} \quad \mathrm{TDS} \mathrm{kg}^{-1}$ fluid (5000 $\mathrm{mg}^{-1}$ ) for the Whitehorse Group, and $0.3 \mathrm{~kg}$ $\mathrm{TDS} \mathrm{kg}^{-1}$ fluid $\left(300,000 \mathrm{mg} \mathrm{l}^{-1}\right.$ ) for the San Andres Formation. On the northeast (right) specified-pressure boundary, the concentrations are the same, except the Ogallala aquifer is given an arbitrary concentration of $0.001 \mathrm{~kg} \mathrm{TDS} \mathrm{kg}^{-1}$ fluid $\left(1000 \mathrm{mg} \mathrm{l}^{-1}\right.$ ) along the Canadian River. The Canadian River is gaining along this reach but carries solute load derived largely from saline seepage in eastern New Mexico (Paine et al., 1994; Mullican et al., 1997). All nodes within the Clear Fork Group were assigned a constant concentration of $0.3 \mathrm{~kg} \mathrm{TDS} \mathrm{kg}^{-1}$ fluid $(30 \mathrm{wt} \% \mathrm{NaCl})$, an approximate value for halite saturation at the depth of interest. For the recharge flux at the top boundary, zero concentration is defined. Solutes neither disperse nor advect across the no-flow boundaries.

\subsection{Model parameters}

Permeability values for modeled hydrologic units are listed in Table 2. Values were taken from Senger and Fogg (1987) and later modified where newer data were available. For salt-dissolution zones, the permeability values range from $10^{-13}$ to $10^{-17} \mathrm{~m}^{2}$ (Dutton, 1989). An average salt-dissolution zone permeability was taken for the Whitehorse Group on the basis of mapping of salt-dissolution zones by Gustavson (1986). Hydraulic conductivity data for the Ogallala aquifer are relatively abundant. Xiang (1996) calculated values ranging from 2.2 to $5.1 \mathrm{~m} \mathrm{day}^{-1}$ for the City of Amarillo Carson County well field (ACCWF). Mullican et al. (1997) calculated hydraulic conductivity values of $0.5-28 \mathrm{~m} \mathrm{day}^{-1}$ from specific capacity tests. For this model, initial permeabilities for the Ogallala aquifer were calculated from existing hydraulic conductivity data and later modified within the range of published values. Vertical permeabilities for the Ogallala aquifer are taken to be an order of magnitude lower than horizontal permeabilities.

The longitudinal and transverse dispersivities listed in Table 2 are estimated values, which are governed in part by the practical limitations imposed by the mesh size. Dispersivities have not been measured in the study area. A discretization rule-of-thumb that guarantees spatial stability for simulation with SUTRA is $\Delta L_{\mathrm{L}} \leq 4 \alpha_{\mathrm{L}}$, where 
Table 2

Model parameters

\begin{tabular}{|c|c|c|c|}
\hline & \multicolumn{2}{|l|}{ Permeability $\left(\mathrm{m}^{2}\right)$} & \multirow[t]{2}{*}{ Porosity } \\
\hline & Horizontal & Vertical & \\
\hline Ogallala aquifer & $4 \times 10^{-12}-4 \times 10^{-11}$ & $4 \times 10^{-13}-4 \times 10^{-12}$ & 0.16 \\
\hline Dockum Gp. & $9.4 \times 10^{-13}$ & $9.4 \times 10^{-14}$ & 0.1 \\
\hline Whitehorse Gp. & $7 \times 10^{-15}$ & $7 \times 10^{-17}$ & 0.1 \\
\hline San Andres Fm. & $9.8 \times 10^{-17}$ & $9.8 \times 10^{-17}$ & 0.05 \\
\hline Clear Fork Gp. & $2.7 \times 10^{-19}$ & $2.7 \times 10^{-19}$ & 0.05 \\
\hline $\begin{array}{l}\text { Model cell thickness (third } \\
\text { dimension) }\end{array}$ & \multicolumn{3}{|l|}{$=1 \mathrm{~m}$} \\
\hline Freshwater density $\left(\rho_{\mathrm{w}}\right)$ & \multicolumn{3}{|l|}{$=1000 \mathrm{~kg} \mathrm{~m}^{-3}$} \\
\hline Fluid viscosity $(\mu)$ & \multicolumn{3}{|l|}{$=10^{-3} \mathrm{~kg} \mathrm{~m} \mathrm{~s}^{-1}$} \\
\hline $\begin{array}{l}\text { Coefficient of fluid density } \\
\text { change }(\partial \rho / \partial C)\end{array}$ & \multicolumn{3}{|l|}{$=700 \mathrm{~kg} \mathrm{~m}^{-3}$} \\
\hline Water compressibility $(\beta)$ & \multicolumn{3}{|l|}{$=4.8 \times 10^{-10} \mathrm{~Pa}^{-1}$} \\
\hline Matrix compressibility $(\alpha)$ & \multicolumn{3}{|l|}{$=1 \times 10^{-8} \mathrm{~Pa}^{-1}$} \\
\hline Longitudinal dispersivity $\left(\alpha_{\mathrm{L}}\right)$ & \multicolumn{3}{|l|}{$=400 \mathrm{~m}$} \\
\hline Transverse dispersivity $\left(\alpha_{\mathrm{T}}\right)$ & \multicolumn{3}{|l|}{$=10 \mathrm{~m}$} \\
\hline Molecular diffusivity $\left(D_{\mathrm{m}}\right)$ & \multicolumn{3}{|l|}{$=1.5 \times 10^{-9} \mathrm{~m}^{2} \mathrm{~s}^{-1}$} \\
\hline Recharge & \multicolumn{3}{|l|}{$=6 \mathrm{~mm}$ year $^{-1}$} \\
\hline Extent of influence of a well $(L)$ & \multicolumn{3}{|l|}{$=700 \mathrm{~m}$} \\
\hline \multicolumn{4}{|l|}{ Well discharge $\left(Q_{\mathrm{w}}\right)$ : } \\
\hline \multirow[t]{2}{*}{ Well B } & \\
\hline & \multicolumn{3}{|c|}{$0.72 \mathrm{~m}^{3} \min ^{-1}(1975-1990)$} \\
\hline Wells $\mathrm{A}$ and $\mathrm{C}$ & \multicolumn{3}{|c|}{$=0.15 \mathrm{~m}^{3} \min ^{-1}$} \\
\hline Pump discharge (line sink) & \multicolumn{3}{|c|}{$=\left(Q_{\mathrm{w}} \times \rho_{\mathrm{w}}\right) / L$} \\
\hline Well B & \multicolumn{3}{|c|}{$=1.05 \times 10^{-2} \mathrm{~kg} \mathrm{~s}^{-1}(1960-1974)$} \\
\hline & \multicolumn{3}{|c|}{$1.71 \times 10^{-2} \mathrm{~kg} \mathrm{~s}^{-1}(1975-1990)$} \\
\hline Wells $\mathrm{A}$ and $\mathrm{C}$ & \multicolumn{3}{|c|}{$=3.58 \times 10^{-3} \mathrm{~kg} \mathrm{~s}^{-1}$} \\
\hline
\end{tabular}

$\Delta L_{\mathrm{L}}$ is the maximum element length along a streamline and $\alpha_{\mathrm{L}}$ is the longitudinal dispersivity. Given a maximum element length parallel to flow of $1400 \mathrm{~m}$, a value of $\alpha_{\mathrm{L}}=400 \mathrm{~m}$ is appropriate. Longitudinal concentration gradients are small in the region and thus the model is not sensitive to longitudinal dispersivity values, despite anisotropic permeabilities in the multilayer model.

Transverse dispersivity $\left(\alpha_{\mathrm{T}}\right)$ values are typically an order of magnitude smaller than longitudinal dispersivity values (Gelhar et al., 1992), but may be as much as two orders of magnitude smaller in systems with anisotropic permeability (Gelhar and Axness, 1983). We assume $\alpha_{\mathrm{T}}=10 \mathrm{~m}$. Matrix compressibility values range from $10^{-8} \mathrm{~Pa}^{-1}$ for sandy gravel to $10^{-10} \mathrm{~Pa}^{-1}$ for sound rock (Domenico and Schwartz, 1997). Because most of the recoverable water is stored in the Ogallala aquifer, a value of $10^{-8} \mathrm{~Pa}^{-1}$ was used in the model. The fluid compressibility (for water at $25^{\circ} \mathrm{C}$ ) was taken to be $4.8 \times 10^{-10} \mathrm{~Pa}^{-1}$. All model parameters are summarized in Table 2 .

\subsection{Steady-state simulation}

To produce reasonable pressure and concentration distributions to represent initial conditions for the pumping simulations, a steady-state variable-density simulation was run. Using boundary conditions described above, a steady-state solution is found by long-term transient simulation from arbitrary initial conditions until the system stabilizes. A recharge flux of $0.038 \mathrm{~kg} \mathrm{~s}^{-1}$ per cross-sectional thickness of $1 \mathrm{~m}\left(6 \mathrm{~mm} \mathrm{year}^{-1}\right)$ is used at the top of the model, which corresponds to the 1959-1960 water table.

In a separate simulation, a specified pressure of zero was assigned to the top layer of the model in 
place of the recharge flux, keeping all other boundary conditions and model parameters unchanged. This was done to test the validity of the recharge flux and to observe whether similar flow dynamics develop using two different representations of the boundary condition. The new representation produced similar flow dynamics, which strengthened our choice of boundary conditions and added support to our original model results. A comparison of velocity profiles along a single row of the model located in the center of the Ogallala aquifer for both simulations gives an average velocity of $0.22 \mathrm{~m} \mathrm{day}^{-1}$ (Fig. 7), which matches well with the average velocity of $0.18 \mathrm{~m} \mathrm{day}^{-1}$ reported by Knowles et al. (1984). The approximate calculated velocity of $0.09 \mathrm{~m} \mathrm{day}^{-1}$ within the paleovalley (at a distance of $60 \mathrm{~km}$ along the cross-section) is in the range of velocities computed from the travel times presented by Mullican et al. (1997) for that area.

A steady-state concentration distribution (Fig. 8) shows three specific regions of elevated concentration in the Whitehorse Group (marked by contour of $0.01 \mathrm{~kg} \mathrm{TDS} \mathrm{kg}^{-1}$ fluid $\left[10,000 \mathrm{mg} \mathrm{l}^{-1}\right]$ ); one is beneath the plume. Incidentally, this is an area where the base of the Ogallala aquifer is also relatively low. The elevated concentration close to the southwest (left) boundary occurs in an area where the tops of the San Andres and the Clear Fork units are angled upwards, but the concentrations drop sharply within a small distance, indicating that the underlying structure is not the primary control. Rather, the small thicknesses of both the overlying Ogallala and Dockum aquifers in that area exert the primary control, resulting in reduced leakance to the Whitehorse Group.

Fig. 8 shows the flow paths and the regions of upward flux interpreted from a velocity vector plot. The flow paths, which are typically on the order of tens of $\mathrm{km}$ and in some places $>100 \mathrm{~km}$ in length, indicate cross-formational discharge influenced by topography. Velocities vary for different flow paths based on the leakance and permeability of units. Beneath the Carson-Gray Counties plume, upward discharge along two different flow paths occurs in the Whitehorse Group. The shorter flow path (30$50 \mathrm{~km}$ length) originates from the northeast (right) side of the paleovalley upgradient of the plume and follows the topographic slope before intercepting the base of the Ogallala aquifer. The longer flow path
$(>100 \mathrm{~km})$ originates largely within the Dockum aquifer. Part of this flow may discharge upward toward the southwest (left) side of the paleovalley, while the rest of it moves within the Whitehorse Group before discharging in the plume area. The upward directed flow at the base of the Ogallala aquifer has velocities ranging from $10^{-7}$ to $10^{-8} \mathrm{~m} \mathrm{day}^{-1}$ and TDS $>3000 \mathrm{mg} \mathrm{l}^{-1}$. The resulting upward discharge is calculated to range from $2 \times 10^{-5}$ to $6 \times 10^{-4} \mathrm{~m}^{3} \mathrm{day}^{-1}$ and the horizontal flow velocities range from $10^{-5}$ to $10^{-4} \mathrm{~m} \mathrm{day}^{-1}$ in the Whitehorse Group.

It is important to note that upward flow occurs only in certain regions of the model, which is consistent with the spatial extent of the zones of higher concentrations within the plume (Fig. 3). The identified flow paths and flow velocities suggest that the upwarddischarging Whitehorse Group waters beneath the Carson-Gray Counties plume could have been recharged during the Pleistocene or earlier times. This observation is consistent with previous interpretations by Dutton $(1989,1995)$ based on ${ }^{14} \mathrm{C}, \delta^{18} \mathrm{O}$, and $\delta \mathrm{D}$ values in salt-dissolution zones and the Dockum aquifer and by Mehta et al. (2000) based on $\delta{ }^{18} \mathrm{O}$ and $\delta \mathrm{D}$ values of plume waters and endmember mixing calculations.

The other two regions of upward discharge identified in the Whitehorse Group occur toward the southwest (left) side of the paleovalley and near the northeast (right) boundary of the model close to the Canadian River (Fig. 8). Despite the upward discharge to the Ogallala aquifer, no saline plume has been reported for these two regions in previous studies. This is probably a result of greater thickness of the Ogallala aquifer in the paleovalley, leading to dilution of salinity, and lack of wells close to the Canadian River, where the saturated thickness is small. The elevated concentrations close to the northeast (right) boundary of the model occur because of upward flow from the Whitehorse Group. The elevated concentrations may in part result from the increased hydraulic gradient and decreased thickness of the Ogallala aquifer, leading to higher horizontal flow velocities (Fig. 7) and decreased vertical leakance in the Whitehorse Group. This region of upward flow in the Whitehorse Group is consistent with the pressure data presented by Bair (1987) and the existence of near-surface salt-dissolution zones 

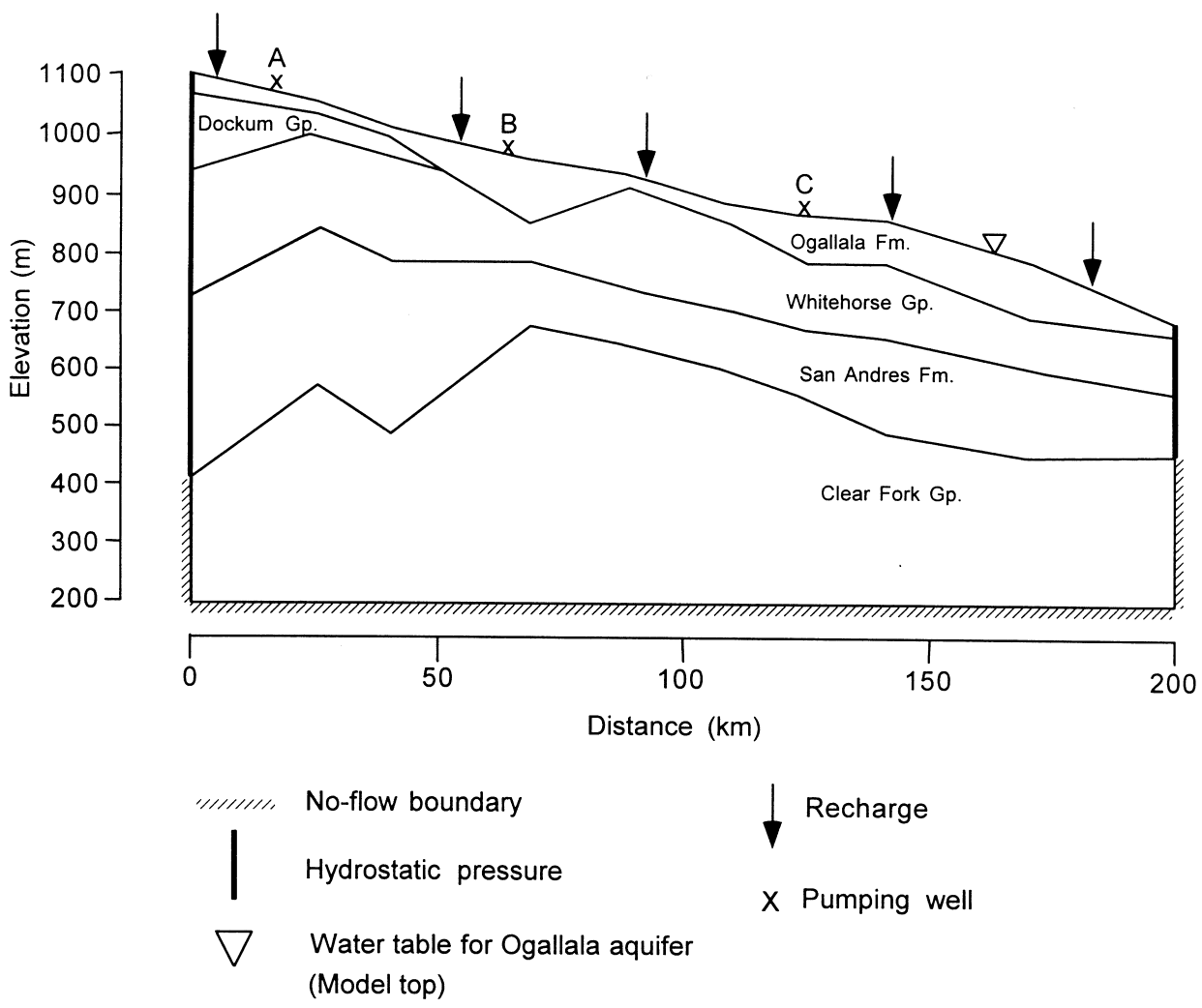

Fig. 6. Model cross-section showing boundary conditions.

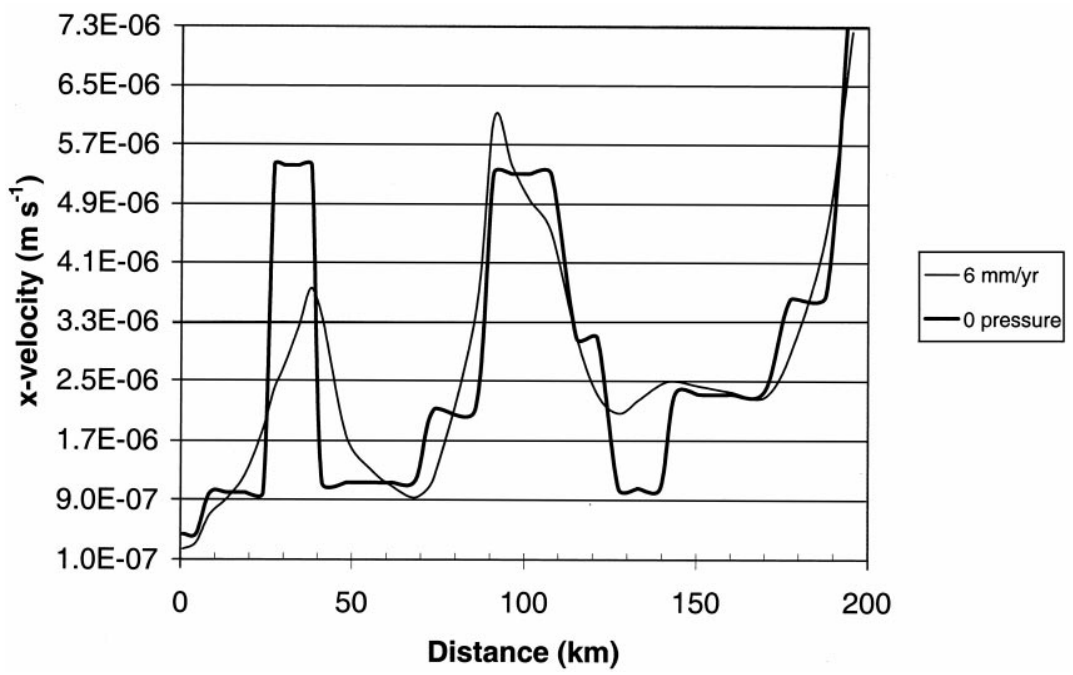

Fig. 7. Model cross-section velocity comparison for Ogallala aquifer (along a row). 

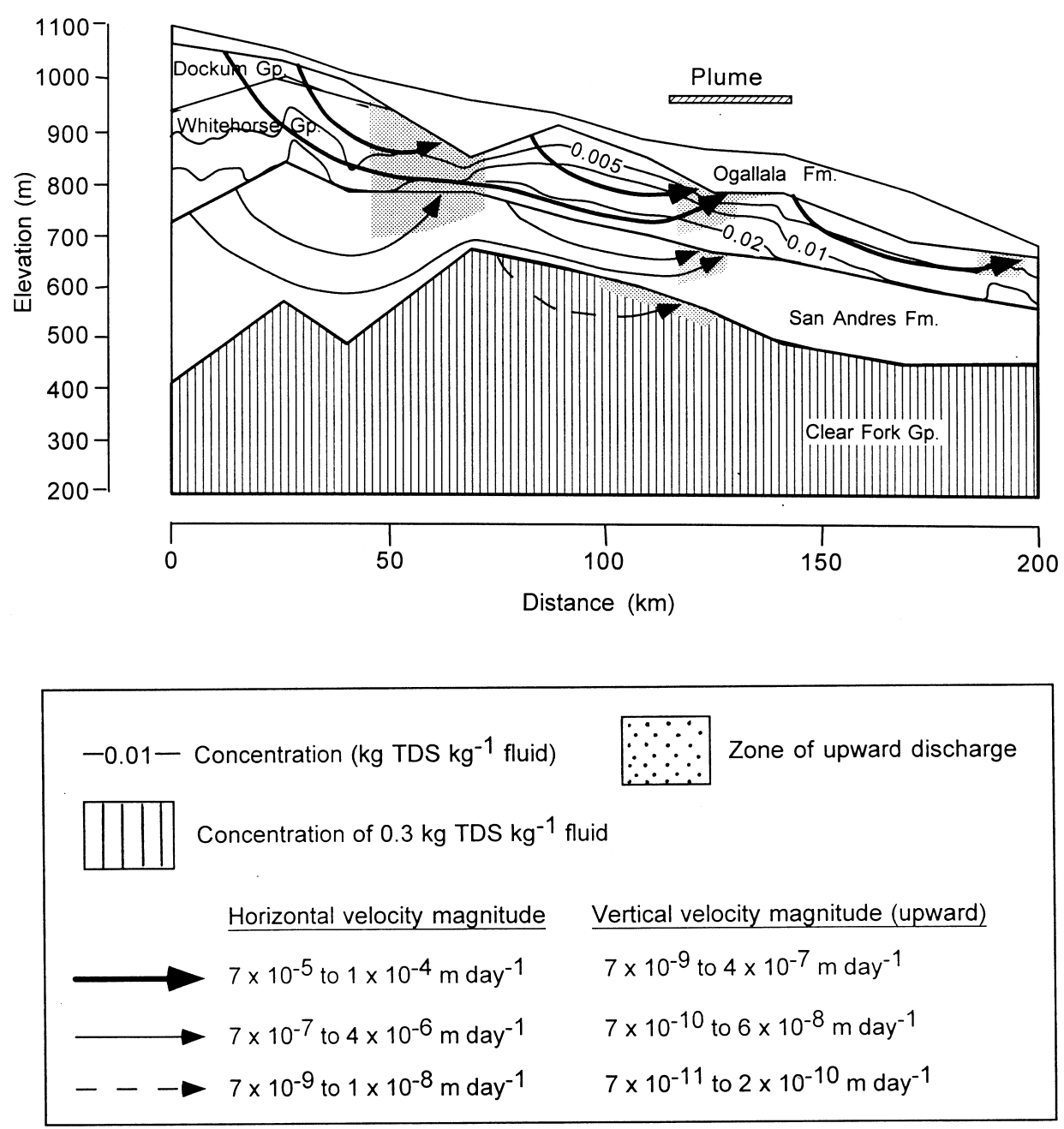

Fig. 8. Concentration distribution ( $\mathrm{kg} \mathrm{TDS} \mathrm{kg}^{-1}$ fluid), flow paths, and regions of upward discharge under steady-state conditions for the model cross-section. Only selected concentration contours and flow paths are shown.

(Gustavson et al., 1980). Furthermore, chemical analyses indicate that brines in the Rolling Plains, east of the Caprock Escarpment, have a shallow meteoric origin rather than a deep-basin origin (Richter and Kreitler, 1986).

Several other flow paths are indicated beneath the Whitehorse Group. Although the flow velocities are smaller, the regions of upward discharge match. The primary controls seem to be the structure and thickness variations within the units themselves relative to the location of recharge areas. The structure and thickness variations have been indirectly affected by the underlying Amarillo uplift and salt-dissolution zones (Gustavson, 1986). Permian strata follow the subsurface rise caused by the uplift and thin at higher elevations near the margins of the adjoining basins. Regions of upward discharge identified generally correspond with the location of observed salt-dissolution zones (Fig. 2).

\subsection{Transient-state simulation}

Transient-state simulations were undertaken to observe the effects of pumping on depressurizing the 


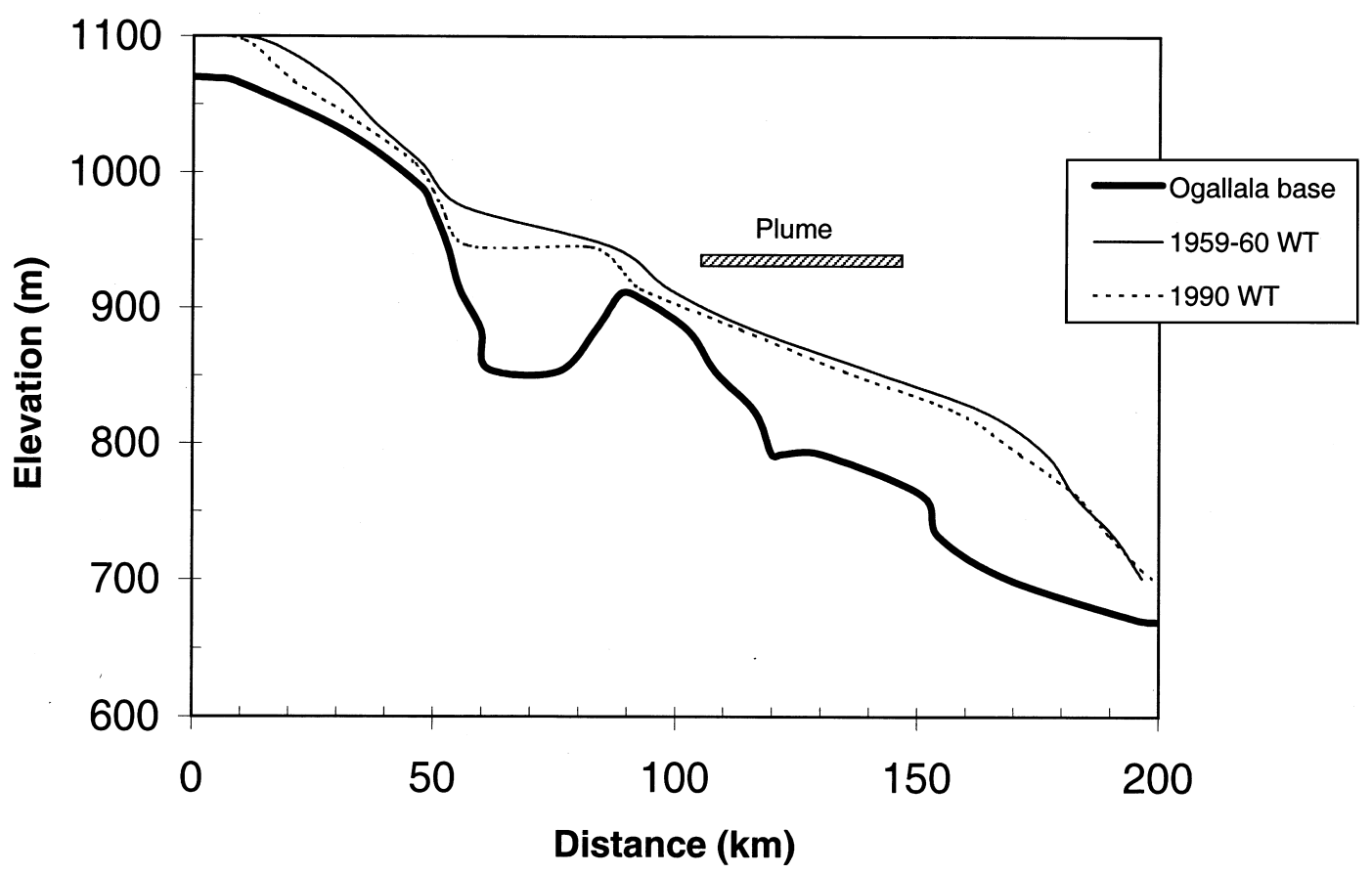

Fig. 9. Profiles for model cross-section comparing 1959-1960 and 1990 water tables.

Ogallala aquifer and on salinity variations. Fig. 9 shows the actual water table variation along the model cross-section between years 1959-1960 and 1990. In most areas, the water-table decline is relatively small, indicating lack of significant pumping in the vicinity of the Carson-Gray Counties plume. The maximum water-table decline observed is in the paleovalley, where the ACCWF is located; the model cross-section passes nearly through the center of the well field (Fig. 1). Along other parts of the crosssection, municipal wells are not known to exist (Coker et al., 1992), so pumping for irrigation is likely to be the main source of discharge. Pumping rates for wells in the ACCWF (from 1960 to 1990) are reasonably well known, but rates for irrigation wells are poorly known. ACCWF wells are pumped yearround; the average production rate per well for the period $1960-1990$ is $0.58 \mathrm{~m}^{3} \mathrm{~min}^{-1}$ (Mullican et al., 1997). This 30 -year period can be divided into two parts, between which the pumping rates changed appreciably. From 1960 to 1974, the pumping was fairly uniform at a rate of $0.44 \mathrm{~m}^{3} \mathrm{~min}^{-1}$ $\left(7.33 \mathrm{~kg} \mathrm{~s}^{-1}\right)$ per well, while the average rate of pumping for the period 1975-1990 was $0.72 \mathrm{~m}^{3} \min ^{-1}\left(12 \mathrm{~kg} \mathrm{~s}^{-1}\right)$ per well. An irrigation well in the study area typically produces at a rate of approximately $2.65 \mathrm{~m}^{3} \mathrm{~min}^{-1}$ for roughly $1500-$ $2000 \mathrm{~h} \mathrm{year}^{-1}$, which is equivalent to an annual rate of $0.45-0.6 \mathrm{~m}^{3} \mathrm{~min}^{-1}$ (Mullican et al.,1997). This pumping rate can vary significantly depending on the type of irrigated crop, area of the irrigated field, and seasonal rainfall.

Three pumping wells (shown in Fig. 6) are simulated for a period of 30 years. Well C is located within the plume, while Well $\mathrm{A}$ is in an area where a significant decline in the water table has occurred. Wells A and $\mathrm{C}$ are considered to be irrigation wells, while Well B simulates an ACCWF well (with the pumping rate changing in 1975 as noted above and in Table 2). In the model we started with an initial value of $0.45 \mathrm{~m}^{3} \mathrm{~min}^{-1}$ to simulate an irrigation well, but we modified the pumping rate to match the observed water levels, which are known with a greater degree of accuracy. The final pumping rate used for each irrigation well was $0.15 \mathrm{~m}^{3} \mathrm{~min}^{-1}\left(2.5 \mathrm{~kg} \mathrm{~s}^{-1}\right)$.

Simulation of a pumping well presents problems 


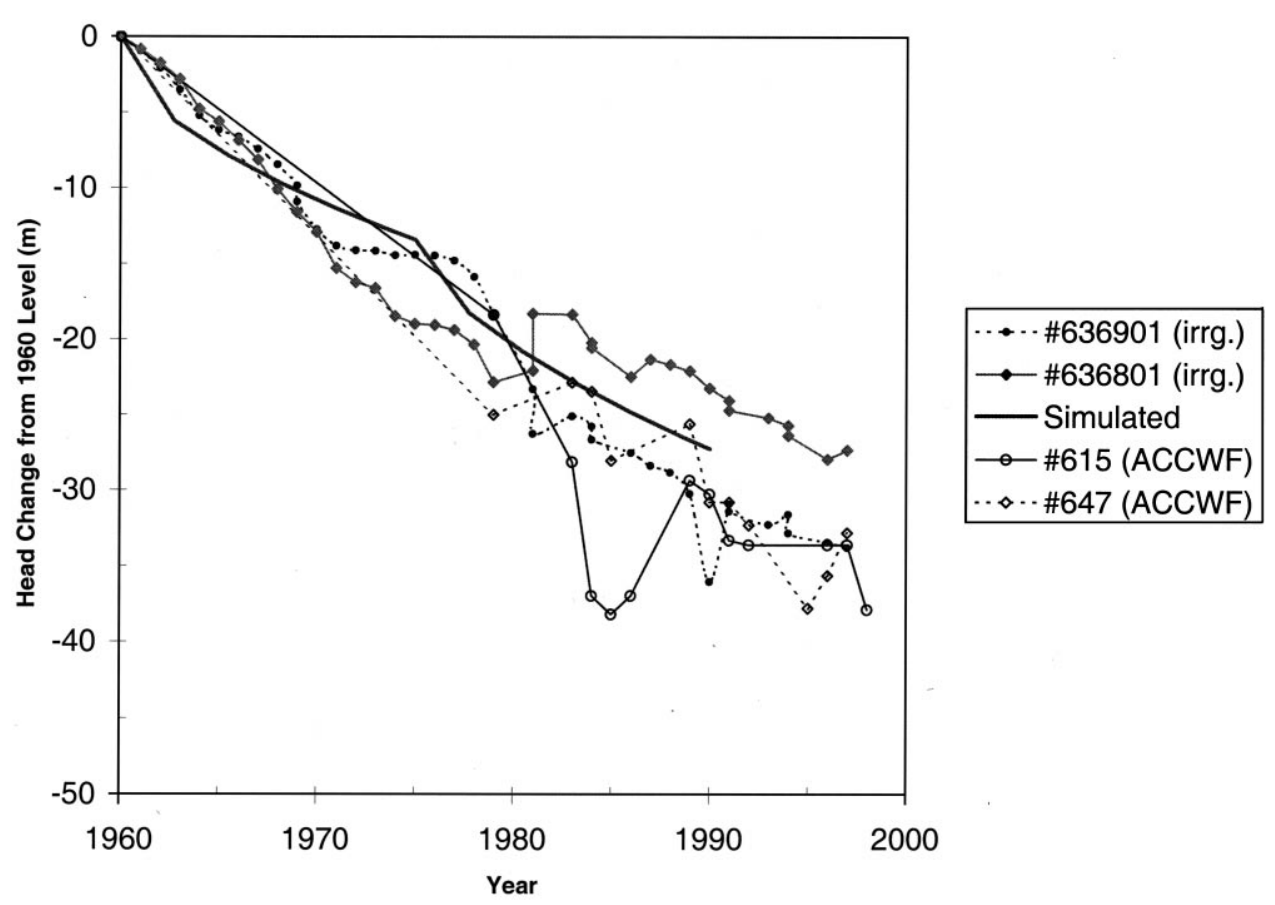

Fig. 10. Simulated water level decline for Well B from 1960 water level after 30 years of pumping, as compared with irrigation wells in the vicinity and wells from ACCWF.

because the flow to the pumping well is convergent and radial, while the two-dimensional model permits only parallel flow in the plane of the model. To overcome this problem, we employed a technique similar to that used by Narayan and Armstrong (1995). The well is replaced by a line sink of magnitude equivalent to the total well discharge divided by the longitudinal extent of the influence of the well. The extent of influence is taken to be $700 \mathrm{~m}$, the approximate minimum spacing between wells in the ACCWF. The value obtained is then equally distributed among nodes representing the bottom two-thirds of the saturated thickness of the Ogallala aquifer, as wells are typically screened in a similar fashion in the region.

Xiang (1996) analyzed the pumping test data for ACCWF wells. He observed steady-state conditions developing within $14 \mathrm{~h}$ of pumping and a late-time delayed drainage effect from release of water from storage. We calculated the storativity $(S)$ by using the formula $S=\rho_{\mathrm{w}} g h S_{\mathrm{op}}$, where $\rho_{\mathrm{w}}$ is the density of fresh water, $g$ the gravitational acceleration, $h$ the saturated thickness, and $S_{\mathrm{op}}$ the specific pressure storativity defined earlier. Considering values of $h$ ranging from 50 to $100 \mathrm{~m}$ (typical for the study area), the calculated values of $S=4 \times 10^{-3}$ to $8 \times$ $10^{-3}$ are in the range of storativity values reported by Xiang (1996) for the Ogallala aquifer.

The result of pumping from Well B is shown in Fig. 10 for the 30-year simulation period. The modeled water-level decline is compared with data from ACCWF wells and irrigation wells in the vicinity on the basis of relative change from the 1960 water level (steady-state conditions). Considering the variability in pumping histories of the wells, a good match exists between the simulated and observed declines. Waterlevel data between 1960 and 1979 are not available for ACCWF wells, although the rate of decline is estimated to be approximately $1 \mathrm{~m}$ year $^{-1}$. Simulation results for Wells $\mathrm{A}$ and $\mathrm{C}$ also compare well with the observed water-level declines. These results show that our choices of model parameters and pumping rates are reasonable.

To study the effect of pumping on changes in 


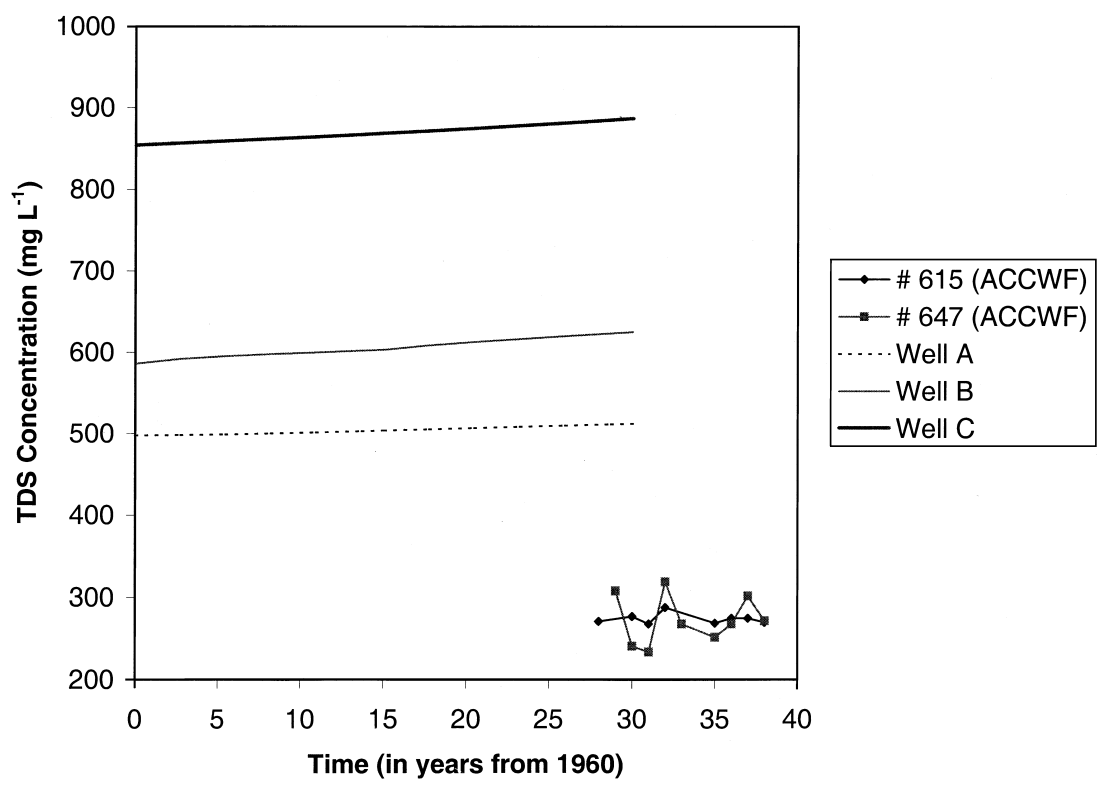

Fig. 11. Simulated variation in TDS concentration with pumping for Wells A, B, and C.

salinity, concentrations are observed at a representative node near the base of the Ogallala aquifer for each of the simulated wells (Fig. 11). A small concentration increase occurs over a period of 30 years. Vertically averaged TDS concentrations from two nearby ACCWF wells are also plotted; these concentrations have not changed appreciably during the period of monitoring (1988-1998). Both ACCWF wells have screened intervals of $>90 \mathrm{~m}$ and have been in operation since 1959. These observations strengthen our finding that pumping has had a negligible effect on salinity distributions in the Ogallala aquifer.

In the underlying Whitehorse Group, the upward velocity component under Well $\mathrm{B}$ increased by as much as three orders of magnitude, while that for Wells A and C increased by as much as two orders of magnitude. The 30 years of continuous pumping has influenced velocities down to a depth of $150 \mathrm{~m}$ below the base of the Ogallala aquifer for Well B and to a depth of $90 \mathrm{~m}$ for Wells A and C. Pumping effects on salinity may become more significant with continued water-table decline.

\subsection{Sensitivity analyses}

A sensitivity analysis was performed to determine the model response to changes in permeability, recharge, dispersivity, diffusion coefficient, and matrix compressibility. Ranges in permeability and recharge rates are constrained by previous modeling and field studies, but ranges in other parameters have not been determined in the field. Because the watertable elevations are well known, any change in recharge rate warrants corresponding changes in the permeability distribution (and vice versa) to simulate the water-table geometry. For a single row in the model within the Ogallala aquifer the calculated average velocities are $0.08 \mathrm{~m} \mathrm{day}^{-1}$ for a recharge of $1.5 \mathrm{~mm} \mathrm{year}^{-1}$ and $0.22 \mathrm{~m}$ day $^{-1}$ for a recharge of $6 \mathrm{~mm}_{\text {year }}{ }^{-1}$. The concentrations observed in the Ogallala aquifer are typically an order of magnitude higher for the recharge rate of $1.5 \mathrm{~mm} \mathrm{year}^{-1}$ compared to those for $6 \mathrm{~mm}_{\text {year }}{ }^{-1}$. The model is fairly insensitive to the vertical permeability within the Dockum aquifer. Decreasing the vertical permeability by an order of magnitude did not appreciably change the velocity distribution in the model. This is probably because the extent of the Dockum aquifer modeled is minor compared to the model size.

Sensitivity analyses for transverse dispersivity and the molecular diffusivity were carried out under steady-state conditions as these parameters do not 
affect the velocity distribution in the Ogallala aquifer. Concentrations were observed for nodes located at Well B across the entire thickness of the Ogallala aquifer. Varying the transverse dispersivity between 1 and $15 \mathrm{~m}$ produced an increase in TDS from about 400 to $650 \mathrm{mg}^{-1}$, while varying the molecular diffusivity between $10^{-10} \mathrm{~m}^{2} \mathrm{~s}^{-1}$ and $10^{-8} \mathrm{~m}^{2} \mathrm{~s}^{-1}$ produced an increase in TDS from about $250 \mathrm{mg}^{-1}$ to $3900 \mathrm{mg} \mathrm{l}^{-1}$. Sensitivity analyses for matrix compressibility were carried out under transient conditions. Varying the matrix compressibility from $10^{-8} \mathrm{~Pa}^{-1}$ to $10^{-10} \mathrm{~Pa}^{-1}$ (two orders of magnitude change) produced a head decline of about 30 to $80 \mathrm{~m}$ in Well B after 30 years of pumping. The model is insensitive to longitudinal dispersivity. Concentrations and velocity distributions do not appear to change for density-dependent vs. nondensity-dependent flow.

\section{Conclusions}

Salinization has affected an area of the Ogallala aquifer $>1000 \mathrm{~km}^{2}$ in the northern part of the Southern High Plains. We mapped two plumes in a four-county area on the basis of chloride and sulfate concentrations. The present areal extent of the Carson-Gray Counties plume is greater than previously reported. Distinct zones of higher salinity within the plume are separated by zones of lower salinity. In higher salinity zones, concentrations increase with depth, as indicated by fluid resistivity logs.

Geochemical studies suggested that the salinity is a result of cross-formational flow from underlying evaporite units, but the actual flow paths were not known. In order to study the flow processes involved and to delineate the factors controlling the plume characteristics, we performed numerical modeling of variable-density flow and solute transport using SUTRA. Three regions (including the observed plume area) have been identified where increased salinity exists within the Whitehorse Group below the Ogallala aquifer. In the southwestern part of the cross-section, the increased salinity is controlled by the geometry of the underlying San Andres Formation and the decreased thickness of the overlying Dockum and Ogallala aquifers. In the other two regions, increased salinity is attributed to natural cross-formational discharge along distinct flow paths as influenced by topography. The flow paths are typically on the order of a few tens of kilometers to more than $100 \mathrm{~km}$ in length. The flow velocities within the Whitehorse Group range from $10^{-7}$ to $10^{-8} \mathrm{~m} \mathrm{day}^{-1}$, and TDS concentrations below the Ogallala aquifer are typically $>3000 \mathrm{mg} \mathrm{l}^{-1}$ where the Dockum Group is absent. The waters present under the Carson-Gray Counties plume, where upward discharge is calculated to range from $2 \times 10^{-5}$ to $6 \times$ $10^{-4} \mathrm{~m}^{3}$ day $^{-1}$, could have been recharged during Pleistocene or earlier times. On-going pumping has had a negligible effect on salinity distributions in the Ogallala aquifer, but has affected velocity distributions in underlying units to depths of $150 \mathrm{~m}$.

Results of this study indicate that salinization of the Ogallala aquifer is a slow, ongoing process. The primary controls on ground-water flow in the study area seem to be the structure and variations in thickness within the various units relative to the location of recharge areas. These variations have been indirectly affected by the underlying Amarillo uplift and salt-dissolution zones. Because the distribution of saline ground water is heterogeneous, careful areal and vertical characterization is warranted prior to well-field development in this region of the Ogallala aquifer.

\section{Acknowledgements}

Our research was supported by grants from the Geological Society of America, the American Association of Petroleum Geologists, the Kentucky Water Resources Research Institute, and the University of Kentucky Graduate School. The US Geological Survey and the Panhandle Groundwater Conservation District \#3 provided in-kind support. We thank the Canadian River Municipal Water Authority, the City of Amarillo, R.W. Harden and Associates, and Lee Wilson and Associates for sharing data, and Cliff Voss and Terry Lahm for advice on modeling. Alan Dutton, Jeffrey Hanor, Bill Thomas, Steve Workman, and an anonymous reviewer provided thoughtful reviews. We appreciate the cooperation of the 
Eakin, Dawkins, Campbell, and McCain families for providing access to their windmills.

\section{References}

Bair, E.S., 1987. Regional hydrodynamics of the proposed highlevel nuclear-waste repository sites in the Texas Panhandle. J. Hydrol. 92, 149-172.

Bassett, R.L., Bentley, M.E., 1983. Deep brine aquifers in the Palo Duro Basin: Regional flow and geochemical constraints. Univ. Tex., Bur. Econ. Geol., Rep. Invest. No. 130, 59pp.

Bein, A., Dutton, A.R., 1993. Origin, distribution, and movement of brine in the Permian Basin (USA): a model for displacement of connate brine. Geol. Soc. Am. Bull. 105, 695-707.

Coker, D., Waterreus, T.C., Peckham, D.S., Ashworth, J.B., 1992. Public supply ground-water use in the northern High Plains of Texas. Tex. Water Development Board Rep. No. 336, 136pp.

Domenico, P.A., Schwartz, F.W., 1997. Physical and Chemical Hydrogeology. Wiley, New York 506 pp.

Dugan, J.T., McGrath, T., Zelt, R.B., 1994. Water-level changes in the High Plains aquifer-predevelopment to 1992. US Geol. Surv., Water Resour. Invest. Rep. No. 94-4027, 56 pp.

Dutton, A.R., 1987. Origin of brine in the San Andres Formation, evaporite confining system, Texas Panhandle and eastern New Mexico. Geol. Soc. Am. Bull. 99, 103-112.

Dutton, A.R., 1989. Hydrogeochemical processes involved in saltdissolution zones, Texas Panhandle, U.S.A. Hydrol. Process. 3, $75-89$.

Dutton, A.R., 1995. Groundwater isotopic evidence for paleorecharge in U.S. High Plains aquifers. Quat. Res. 43, 221-231.

Dutton, A.R., Orr, E.D., 1986. Hydrogeology and hydrochemical facies of the San Andres Formation in eastern New Mexico and the Texas Panhandle. Univ. Tex., Bur. Econ. Geol., Rep. Invest. No. $157,58 \mathrm{pp}$.

Dutton, A.R., Richter, B.C., Kreitler, C.W., 1989. Brine discharge and salinization, Concho River watershed, West Texas. Ground Water 27, 375-383.

Dutton, A.R., Simpkins, W.W., 1986. Hydrogeochemistry and water resources of the Triassic lower Dockum Group in the Texas Panhandle and eastern New Mexico. Univ. Tex., Bur. Econ. Geol., Rep. Invest. No. 161, 51pp.

Dutton, A.R., Simpkins, W.W., 1989. Isotopic evidence for paleohydrologic evolution of ground-water flow paths, Southern Great Plains, U.S.A. Geology 17, 653-656.

Dutton, S.P., Goldstein, A.G., Ruppel, S.C., 1982. Petroleum potential of the Palo Duro basin, Texas Panhandle. Univ. Tex., Bur. Econ. Geol., Rep. Invest. No. 123, 87pp.

Eifler, G.K., Jr., Barnes, V.E., 1969. Amarillo sheet. Geologic Atlas of Texas, scale 1:250,000. Univ. Tex., Bur. Econ. Geol.

Fishman, M.J., Friedman, L.C., 1989. Methods for determination of inorganic substances in water and fluvial sediments. U.S. Geol. Surv., Techniques of Water-Resour. Invest., Book 5, Ch. A1, 545pp.

Gelhar, L.W., Axness, C.L., 1983. Three dimensional stochastic analysis of macrodispersion in aquifers. Water Resour. Res. 19, 161-180.
Gelhar, L.W., Welty, C., Rehfeldt, K.R., 1992. A critical review of data on field-scale dispersion in aquifers. Water Resour. Res. 28, 1955-1974.

Gustavson, T.C., 1986. Geomorphic development of the Canadian River Valley, Texas Panhandle: an example of regional salt dissolution and subsidence. Geol. Soc. Am. Bull. 97, 459-472.

Gustavson, T.C., Finley, R.J., McGillis, K.A., 1980. Regional salt dissolution in the Anadarko, Dalhart, and Palo Duro Basins of the Texas Panhandle. Univ. Tex., Bur. Econ. Geol., Rep. Invest. No. 106, 40pp.

Gutentag, E.D., Heimes, F.J., Krothe, N.C., Luckey, R.R., Weeks, J.B., 1984. Geohydrology of the High Plains aquifer in parts of Colorado, Kansas, Nebraska, New Mexico, Oklahoma, South Dakota, Texas, and Wyoming. U.S. Geol. Surv., Prof. Pap. No. 1400-B, 63pp.

Harden, R.W. and Associates, Inc., 1999a. Test drilling data for SAA water rights, Roberts County, Tex., March-April 1999. Prepared for City of Amarillo, Amarillo, Tex., USA.

Harden, R.W. and Associates, Inc., 1999b. Results of test drilling SAA water rights, Roberts County, Tex., March-April 1999. Prepared for City of Amarillo, Amarillo, TX, USA.

Jorgensen, D.G., Downey, J., Dutton, A.R., Maclay, R.W., 1988. Region 16, central nonglaciated plains. In: Back, W., Rosenshein, J.S., Seaber, P.R. (Eds.), Hydrogeology. Geol. Soc. Am., The Geology of North America, O-2, pp. 141-156.

Knowles, T., Nordstrom, P., Klemt, W.B., 1984. Evaluating the ground-water resources of the High Plains of Texas, vol. 1. Tex.. Dept. Water Resour. Rep. 288-1, 119pp.

Lahm, T.D., Bair, E.S., VanderKwaak, J., 1998. Role of salinityderived variable-density flow in the displacement of brine from a shallow, regionally extensive aquifer. Water Resour. Res. 34, 1469-1480.

Long, A.T., Jr., 1961. Geology and ground-water resources of Carson and part of Gray County, Texas, progress report no. 1. Tex. Board Water Engineers Bull. 6102, 45pp.

Luckey, R.R., Becker, M.F., 1999. Hydrogeology, water use, and simulation of flow in the High Plains aquifer in northwestern Oklahoma, southeastern Colorado, southwestern Kansas, northeastern New Mexico, and northwestern Texas. U.S. Geol. Surv., Water Resour. Invest. Rep. No. 99-4104, 68pp.

McAdoo, G.D., Leggat, E.R., Long, A.T., 1964. Geology and ground-water resources of Carson County and part of Gray County, Texas, progress report no. 2. Tex. Water Commission Bull. 6402, 27pp.

McGookey, D.A., Gustavson, T.C., Hoadley, A.D. 1988. Regional stratigraphic cross sections. Mid-Permian to Quaternary strata, Texas Panhandle and Eastern New Mexico: Distribution of evaporites and areas of evaporite dissolution and collapse. Univ. Tex., Bur. Econ. Geol., Cross Sections No. 8.

Mehta, S., Fryar, A.E., Banner, J.L., 2000. Controls on the regionalscale salinization of the Ogallala aquifer, Southern High Plains, Texas, USA. Appl. Geochem. 15, 849-864.

Mullican, W.F., III, Johns, N.D., Fryar, A.E., 1997. Playas and recharge of the Ogallala aquifer on the Southern High Plains of Texas-An examination using numerical techniques. Univ. Tex., Bur. Econ. Geol., Rep. Invest. No. 242, 72pp. 
Narayan, K.A., Armstrong, D., 1995. Simulation of groundwater interception at Lake Ranfurly, Victoria, incorporating variable density flow and solute transport. J. Hydrol. 165, 161-184.

Nativ, R., Smith, D.A., 1987. Hydrogeology and geochemistry of the Ogallala aquifer, Southern High Plains. J. Hydrol. 91, 217-253.

Paillet, F.L., Zaghloul, E.S., Dafter, T.E., 1990. Applications of geophysical well log analysis to characterization of aquifers in the Sinai region, Republic of Egypt. U.S. Geol. Surv., Water Resour. Invest. Rep. No. 90-4194, 54pp.

Paine, J.G, Avakian, A.J., Gustavson, T.C., Hovorka, S.D., Richter, B.C., 1994. Geophysical and geochemical delineation of sites of saline-water inflow to the Canadian River, New Mexico and Texas. Univ. Tex., Bur. Econ. Geol., Rep. Invest. No. 225, 73pp.

Richter, B.C., Kreitler, C.W., 1986. Geochemistry of salt water beneath the Rolling Plains, north-central Texas. Ground Water 24, 735-742.

Rogers, D.B., Dreiss, S.J., 1995. Saline groundwater in Mono Basin, California. 1 Distribution. Water Resour. Res. 31, 3131-3150.

Sanford, W.E., Wood, W.W., 1991. Brine evolution and mineral deposition in hydrologically open evaporite basins. Am. J. Sci. 291, 687-710.

Scanlon, B.R., Goldsmith, R.S., 1997. Field study of spatial variability in unsaturated flow beneath and adjacent to playas. Water Resour. Res. 33, 2239-2252.

Segol, G., Pinder, G.F., 1976. Transient simulation of saltwater intrusion in southeastern Florida. Water Resour. Res. 12, 65-70.

Senger, R.K., 1993. Paleohydrology of variable-density groundwater flow systems in mature sedimentary basins: Example of Palo Duro Basin, Texas, USA. J. Hydrol. 151, 109-145.

Senger, R.K., Fogg, G.E., 1987. Regional underpressuring in deep brine aquifers, Palo Duro Basin, Texas, 1, Effect of hydrostratigraphy and topography. Water Resour. Res. 23, 1481-1493.

Senger, R.K., Fogg, G.E., 1990. Stream functions and equivalent fresh-water heads for modeling regional flow of variable-density ground water, 2, Applications and implications for modeling strategy. Water Resour. Res. 26, 2097-2106.

Simmons, C.T., Narayan, K.A., 1998. Modelling density-dependent flow and solute transport at the Lake Tutchewop saline disposal complex, Victoria. J. Hydrol. 206, 219-236.

Souza, W.R., Voss, C.I., 1987. Analysis of an anisotropic coastal aquifer system using variable-density flow and solute transport simulation. J. Hydrol. 92, 17-41.

Stein, R., Schwartz, F.W., 1990. On the origin of saline soils at Blackspring Ridge, Alberta, Canada. J. Hydrol. 117, 99-131.

Voss, C.I., 1984. SUTRA: A finite-element simulation model for saturated-unsaturated fluid-density-dependent ground-water flow with energy transport or chemically reactive single-species solute transport. U.S. Geol. Surv., Water Resour. Invest. Rep. No. 84-4369, 409pp.

Voss, C.I., Boldt, D., Shapiro, A.M., 1997. A graphical-user interface for the U.S. Geological Survey's SUTRA code using Argus ONE (for simulation of variable-density saturated-unsaturated ground-water flow with solute or energy transport). U.S. Geol. Surv., Open File Rep. No. 97-421, 106pp.

Wood, W.W., Sanford, W.E., 1995. Eolian transport, saline lake basins, and groundwater solutes. Water Resour. Res. 31, 3121-3129.

Xiang, J., 1996. Evaluation of hydraulic conductivity of Carson County Well Field, Amarillo, Texas. Ground Water 34, 1042-1049. 